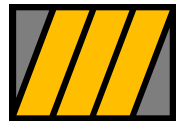

ESCUELA DE NEGOCIOS

Universidad Torcuato Di Tella

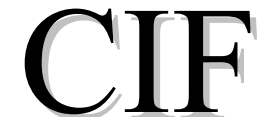

Centro de Investigación en Finanzas

Documento de Trabajo 14/2003

\title{
Financial Dollarization and Debt Deflation under a Currency Board
}

\author{
Sebastián Galiani \\ Universidad de San Andres \\ Eduardo Levy Yeyati \\ Universidad Torcuato Di Tella \\ Ernesto Schargrodsky \\ Universidad Torcuato Di Tella
}
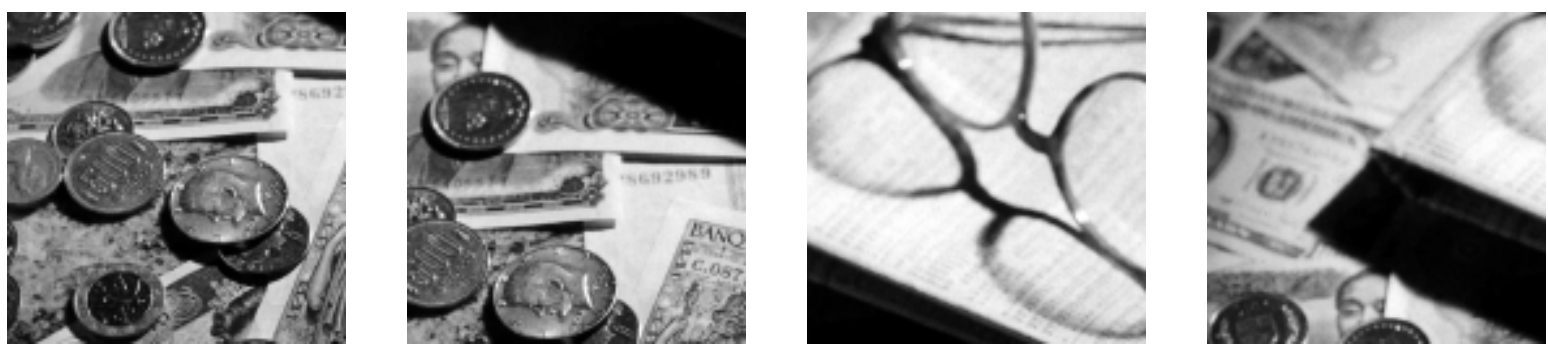

Miñones 2177, C1428ATG Buenos Aires • Tel: 4784.0080 interno 181 y 4787.9394 • Web 


\title{
Financial Dollarization and Debt Deflation under a Currency Board
}

\author{
Sebastian Galiani \\ Universidad de San Andres \\ Eduardo Levy Yeyati \\ Universidad Torcuato Di Tella \\ Ernesto Schargrodsky* \\ Universidad Torcuato Di Tella
}

September 12, 2003

\begin{abstract}
In the late currency board years, Argentina faced a real exchange rate adjustment through price deflation amidst growing devaluation expectations. Using a firm-level panel database to analyze the incidence of these factors on the currency composition of private debt and on firms' performance, we find that widespread debt dollarization showed no relationship with the firms' production mix or the ever-changing probability of a nominal devaluation. While relative price changes favored export-oriented firms with the expected impact on sales, earnings and investment, increases in devaluation expectations elicited only a marginal differential response in investment from more financially dollarized firms. Our findings provide support to two criticisms faced by the Argentine currency board in recent years, namely, that by fueling beliefs in an implicit guarantee it stimulated across-the-board debt dollarization, and that it could not fully isolate the economy from real shocks, as the feared balance sheet effect was replaced by a gradual but equally deleterious debt deflation effect.
\end{abstract}

\footnotetext{
* Sebastian Galiani, Professor, Universidad de San Andres, Vito Dumas 284, (B1644BID) Victoria, Provincia de Buenos Aires, Argentina, Tel.: (54-11) 4746-2608, sgaliani@udesa.edu.ar. Eduardo Levy Yeyati, Professor, Universidad Torcuato Di Tella, Miñones 2177, (C1428ATG) Buenos Aires, Argentina, Tel.: (54-11) 4784-0080, ely@utdt.edu. Ernesto Schargrodsky, Professor, Universidad Torcuato Di Tella, Miñones 2177, (C1428ATG) Buenos Aires, Argentina, Tel.: (54-11) 4784-0080, eschargr@utdt.edu. This paper benefited from comments by the editor Campbell Harvey, Kristin Forbes, Arturo Galindo, Ugo Panizza, Fabio Schiantarelli and participants at the IDB Boston College conference on Balance Sheet Effects and Fluctuations. Sebastian Calonico and Maria Eugenia Garibotti provided excellent research assistance.
} 


\section{Introduction}

Firm-level effects of exchange rate volatility have been increasingly at the center of the exchange rate regime debate for developing economies. In a nutshell, the so-called "balance sheet" approach emphasizes that, by funding domestic credit in a foreign currency (either through dollarized domestic savings or through foreign borrowing), systemic exposure to exchange rate risk increases either at the bank level (if financial regulations allow institutions to run unbalanced foreign currency positions) or, more typically, at the firm level (more precisely, through the exchange rate risk exposure of dollar indebted non-dollar earners). This approach has been used to argue against attempts to deepen financial intermediation in emerging economies through increased reliance on a foreign currency, and to criticize exchange rate-based stabilizations that induce financial dollarization through the perception of a public exchange rate guarantee. On the other hand, it has also been used to explain the propensity of developing economies to reduce exchange rate volatility under any de jure exchange rate regime, and to argue in favor of the adoption of superfixed exchange rate arrangements (including unilateral dollarization). ${ }^{1}$

Exchange rate-related balance sheet effects, however, are a more general phenomenon ultimately derived from the lack of a strong national currency. Emerging economies tend to have weak currencies, namely, currencies that are not accepted as store of value either domestically or internationally. In the domestic case, the immediate symptom is that the public prefers to save mainly in a foreign currency (inducing financial dollarization) or, if this is restricted by the monetary authorities, in short-term local currency assets or directly offshore. As a result, when financial dollarization is allowed, debtors from the non-tradable sector end up with debts denominated in tradables, increasing their exchange rate exposure. On the contrary, when not dollarized, "a country with a weak currency displays pronounced short-termism in financial contracts, with investors lured towards the peso by instruments that re-price very frequently (e.g., deposits with interest rates that adjust daily in line with the overnight rate)."

Although, in general, partially dollarized weak currency economies are likely to suffer from both currency and maturity mismatches, intuitively, countries where the first one is prevalent will tend to carefully manage their exchange rates while those where the second problem dominates will adapt their monetary policy in order to minimize the real effects of an interest rate defense of the exchange rate. Thus, irrespective of the de jure regime reported by the country, the de facto exchange rate policy will be to a large degree determined by the relative importance of currency and maturity mismatches, and their perceived consequences. ${ }^{3}$

While the literature has tended to focus on the adverse effects of an unexpected nominal devaluation in the presence of (bank- or firm-level) currency mismatches, it is essential to note that a superfixed regime that successfully prevents a sharp nominal devaluation does not protect a country from the balance sheet effects of a real exchange rate (RER) adjustment. On the contrary, under a peg, RER overvaluation is corrected through a process of deflation that reduces the relative price of non-tradables eroding the capacity to pay of debtors from the non-tradable

\footnotetext{
${ }^{1}$ Examples include De la Torre et al. (2002), Ize and Levy Yeyati (2003) and Burnside et al. (2001), in the first case, and Calvo (2002), Calvo and Reinhart (2002) and Haussman, Panizza and Stein (2001), in the second. By financial dollarization we refer to the holding by residents of foreign currency-denominated assets and liabilities.

${ }^{2}$ De la Torre, Levy Yeyati and Schmukler (2002). Argentina is a good example of the first type: in the currency board period, financial dollarization was not only tolerated but also fostered by the authorities. A good example of the second type is Brazil, where not only dollar intermediation is severely restricted but also interest rate indexation has been widely used in the past as a "policy crutch" to bolster financial intermediation in the local currency.

${ }^{3}$ See Levy Yeyati and Sturzenegger (2002), and references therein.
} 
sector regardless of the currency of denomination of their loans, in line with Fisher's (1933) classical "debt deflation" argument. By contrast, in a country without financial dollarization, the adjustment to a more depreciated equilibrium RER that comes through nominal depreciation of a flexible exchange rate improves (via debt dilution) the capacity to pay of debtors in the nontradable sector, partially offsetting the negative impact of the devaluation from the rise in the price of tradable inputs. ${ }^{4}$ Balance sheet and debt deflation effects can be regarded to a large extent as two sides of the same real exchange rate exposure problem in dollarized economies.

In spite of their growing importance in both policy and theoretical debates, the empirical relevance of balance sheet and debt deflation effects remains largely an open question. The analytical literature contrasts with the scarcity of empirical studies assessing the real magnitude of these effects. Among the few available articles, Bleakley and Cowan (2002) analyze the effect on investment of holding foreign-currency denominated debt during devaluations using a sample of 500 non-financial publicly traded companies from five Latin American countries. They find that the expansionary competitiveness effect associated to exchange-rate realignments offsets the potential contractive balance sheet effect on investment. They also find that, after depreciations, earnings are higher for firms holding more dollar debt, suggesting the presence of investment opportunities that arise from the change in relative prices. Thus, the authors conclude that there is no severe currency mismatch of output and liabilities. Firms match the currency composition of their debt with the exchange rate elasticity of their income.

Forbes (2002) analyzes firm effects on publicly traded companies from 42 countries to examine the impact of 12 major currency depreciations. She finds no significant debt effects on performance after depreciations (the currency composition of debt is not analyzed), although firms with higher debt ratios tend to show lower net income growth. As expected, firms with a higher share of foreign sales exposure perform better after depreciations. In the year after depreciations, firms show larger growth in market capitalization than in net income suggesting that the reallocation of resources forced by devaluations need time to materialize, although these effects are anticipated by market values. ${ }^{5}$

A series of articles look at the determinants of capital structure and balance sheet effects for Mexican companies around the Tequila crisis. Martinez and Werner (2002) find that, during the fixed exchange-rate period before the December 1994 crisis, companies show no relationship between the currency composition of their debt and output. Instead, under a floating regime after the crisis, companies are less likely to show currency mismatches between debt and output. These results are contradicted by Aguiar (2002) and Gelos (2003), who find a positive relationship between firms' foreign-currency denominated debt and exports before the Tequila crisis. In an related piece, Harvey and Roper (1999), in the context of the Asian crises, presents evidence that Asian corporations "bet" on the stability of the exchange rate by favoring less

\footnotetext{
${ }^{4}$ See Obstfeld (2001). Moreover, if the debt bears fixed interest rates (as is usually the case in Argentina), peso debt behaves countercyclically, as non-tradable producers benefit from the partial pass-through of a nominal devaluation to domestic prices while the debt burden remains constant. Real exchange rate risk, in this case, is born by the lender.

${ }^{5}$ Campa and Goldberg (1999) and Nucci and Pozzolo (2001) consider the effect of exchange rate fluctuations on investment decisions at the industry and firm level, respectively. They find that positive effects of a depreciation of the local currency are associated to larger shares of exports as percentage of total firm production, and negative effects are associated to the share of imported inputs. While these studies do not consider balance sheet effects directly (and use no financial information), the reported effects of exchange rate suggest that firms are not perfectly hedged against exchange rate risk
} 
costly dollar debt at a time of declining profitability, benefiting with higher short-term returns at the expense of a larger currency exposure that ultimately exacerbated the extent of the crisis.

Our paper intends to contribute to this growing literature by looking at balance sheet in the late years of the Argentine currency board. While most of the literature on balance sheet effects focuses on fluctuations in the nominal exchange rate, either under a flexible regime or as a result of the collapse of a peg, our study addresses the impact of debt deflation, namely, the effect of an adverse external shocks under a peg through changes in the real exchange rate and price deflation in the local currency. As price deflation induces increases in the real value of the debt regardless of the currency denomination, balance sheet effects through both dollar and peso denominated debt are considered in our study.

Our focus lies on two potentially relevant effects stressed by the analytical literature: i) the incidence of exchange rate policy on the currency composition of private debt, and ii) the incidence of real shocks on firms with real exchange rate exposures. The first issue relates to the presence of implicit guarantees provided by fixed exchange rate regimes. The relevant question is whether a peg creates an implicit exchange rate guarantee that reduces the firms' willingness to pay the cost of hedging their positions (in the case of non-tradable producers, by paying the additional cost of peso funding). ${ }^{6}$

The second issue is directly related to the implications of a pegged exchange rate regime and to the dilemma between nominal deflation and devaluation (alternatively, debt deflation or balance sheet effects) as a response to a substantial RER misalignment. While in principle there is a symmetry between the two as both eventually converge to an equilibrium RER level, in practical terms there is a tradeoff between gradualism (at the cost of a long recession) and shock therapy (at the cost of abrupt financial disruptions). In the Argentine experience analyzed in this paper, the effects are entirely generated by the gradual deflation process. By contrast, no conclusion can be extracted concerning standard devaluation-related balance sheet effects based on the sample analyzed in this study, as the nominal exchange rate was kept constant over the period. $^{7}$

The map of this paper is as follows. Section 2 describes the period of analysis and provides some basic macroeconomic background. Section 3 presents our data. Section 4 lists the hypotheses to be tested empirically. Section 5 describes the methodological approach. Section 6 discusses the empirical results, and section 7 concludes.

\footnotetext{
${ }^{6}$ Note that prudential norms in the financial sector limited at the time the exposure to exchange rate risk at the bank level, but were completely silent regarding currency mismatches at the firm level. In particular, no discrimination was made in relation to the tradable component of debtors' production mix. From a normative perspective, the question intends to explore whether firms in the non-tradable sector internalized the risk associated with a currency mismatch between earnings and financial costs. For more general discussions on ways in which a peg may induce financial dollarization, see Ize and Levy Yeyati (2003), Burnside, Eichembaum and Rebelo (2001) and Broda and Levy Yeyati (2003). See also the discussion of the empirical evidence in Harvey and Roper (1999).

${ }^{7}$ Indeed, the pesification (that is, the compulsory conversion of dollar liabilities at the one-to-one exchange rate) of all domestic liabilities that followed the January 2002 devaluation all but eliminated any potential balance sheet effect, so that an assessment of the latter in Argentina will remain a speculative issue. A proxy analysis can still be conducted based on external corporate exposure, exploiting the fact that external debt could not be unilaterally converted. The impact, however, is also muted here, since most of this debt is in the process of being renegotiated under the umbrella of the sovereign default and extensive controls to capital transfers.
} 


\section{Macroeconomic Setting}

Exploring the empirical answer to our questions requires the combination of widespread financial dollarization with an important variability in both real exchange rate and devaluation expectations. The late 1990s in Argentina satisfy these requirements. Dollarization was extensive at both sides of the banks' balance sheet. The real exchange rate went through important variations as the steady appreciation of the dollar that characterized the 1990s compounded with the stream of devaluations triggered by the Asian crises and the Russian default that led, finally, to the devaluation of the Brazilian real in 1999. As a result, the latest Convertibility years witnessed a contractionary adjustment through price deflation. Moreover, these external shocks fueled sizable and volatile devaluation expectations. We exploit these elements, plus a rich firmlevel panel database, to investigate the response of debt composition and performance to real exchange rate changes. Table 1 presents a summary of the major economic and political events during the Convertibility period. The evolution of key macroeconomic variables is illustrated in Appendix $1 .^{8}$

We analyze the period from 1993 to 2001 . The study starts in 1993 as data quality and availability becomes poorer for earlier years. Our last observations correspond to 2001, right before the devaluation and pesification of loans and deposits that ended the Argentine currency board period. Thus, our sample comprises almost all the Convertibility era including the Tequila crisis and the final recession that started in 1998.

\section{Data Description}

\section{Our Sample}

As explained, we study the evolution of companies' balance sheets from 1993 to 2001 . We consider annual observations using information from companies' statements. ${ }^{9}$ We restrict our sample to non-financial companies. Given that currency mismatches are affected by banking regulation, the capital structure of banks is not comparable with the behavior of non-financial companies. As our estimation methodology requires the use of lagged variables as instruments, we exclude companies for which balances are not available for some intermediate year. To avoid having a panel of very short duration, we also exclude companies for which there are less than four years of information after 1995. Our sample of firms is composed of three types of companies: publicly traded companies, publicly held but not publicly traded companies, and privatized companies.

Information from publicly traded companies is available from the Buenos Aires Stock Exchange. We consider all the non-financial publicly traded companies for which there is a minimum of four observations from contiguous years since 1995. A total of 71 companies satisfy these conditions. The data for these publicly traded companies were obtained from the financial data company Economatica.

\footnotetext{
${ }^{8}$ For a detailed account of the Argentine economy over the currency board period, see Levy Yeyati (2001) and references therein.

${ }^{9}$ A table with variable definitions and sources used in the paper is presented in Appendix 2
} 
We also took advantage of the fact that a large number of formerly state-owned companies were privatized in Argentina. The privatization process took place during the period 1990-98. Although most of these companies are not publicly traded, they are obliged to report their financial information to the regulatory agencies. We followed the balance sheets presented by the privatized companies to the regulatory agencies of the Air Transport, Airports, Electricity, Gas, Telecommunications, Water and Sewerage, Railways, and Postal Services sectors. Financial data for a total of 56 non-financial privatized companies (with at least four observations for contiguous years since 1995) were obtained through this process.

We completed our database tracking data for non-publicly-traded non-privatized companies. Some companies, although not publicly traded, present regularly their financial information to the Buenos Aires Stock Exchange because they have issued publicly traded debt bonds, or because they intend to be publicly traded at some point. Data for 18 non-financial firms of this type were obtained directly from the Buenos Aires Stock Exchange. Finally, companies that are publicly held but not publicly traded and that incorporated in the city of Buenos Aires have to present their annual balances to the General Inspection of Justice (the enforcement of this rule is somewhat loose). We requested to this public office the financial information for the top 100 firms (according to the 2001 ranking of sales of the specialized business magazine Mercado) not covered by the other sources of information described above. Data for 57 non-financial nonpublicly traded companies (with at least four observations from contiguous years since 1995) were obtained through this procedure.

Thus, our database comprises a total of 202 firms. Table 2 summarizes the number of companies and observations available for each year. The panel gets thinner for the first years because of data unavailability and because some companies were privatized after 1993. It is also thinner for 2001 because of companies' delays during the 2002 crisis in presenting their financial information. the complete list of firms included in the study and the years for which data are available for each company are reported in Galiani et al. (2003).

We classify the companies in our sample according to their main sector of economic activity (at CIIU-2 digit level). For each of these CIIU sectors we have available a price index that will allow us to measure relative price movements. The 202 companies participate in 33 sectors. We then classify these sectors as tradable or non-tradable according to their production composition. We perform this classification at the sector level using information from the Argentine national accounts, because company data do not disaggregate between domestic and external sales. In Table 3, a firm is classified as tradable if the expo share (the 1993-2001 average of the ratio of exports over total value added) of its sector of activity is larger than the median of the sector export shares across all the companies in our sample. ${ }^{10}$ This procedure divides our sample in a tradable half and a non-tradable half.

Table 4 reports the summary statistics for all the observations of our sample for selected variables of interest splitting the sample between tradable and non-tradable companies. A main finding is noteworthy and anticipatory of our results. It appears to be no correlation between the tradable nature of firms' output and the currency composition of their debt. Tradable and nontradable companies show very similar debt and dollar-debt ratios. ${ }^{11}$ If anything, non-tradable

\footnotetext{
${ }^{10}$ We obtain similar results by classifying our firms as tradable when they belong to the agriculture, mining or manufacturing sector, and as non-tradable for the other sectors.

${ }^{11}$ These numbers, in turn, are consistent with the level of financial dollarization observed for the whole economy (Figure A3).
} 
firms display a slightly higher level of debt dollarization. This contrasts with what one would expect in the absence of exchange rate guarantees and given the deflationary period of the late 1990s. On the other hand, the table reveals that tradable producers were favored by the relative price changes over the period. Prices followed the GDP deflator very closely for the tradable sectors, while they displayed a decline of around $10 \%$ for the non-tradable sector.

There is also little difference concerning the other variables. Companies in both sectors seem to have, on average, similar size according to assets. The evolution of sales over assets was similar across sectors. During the period of analysis, non-tradable companies show larger investment and earnings. By construction, the export (and import) shares of the firms classified as tradable producers are obviously larger than for the non-tradables. Table 5 presents the same data in more detail, ordering sectors according to their export content. Again, no apparent pattern appears relating tradable content of the production mix and dollar debt ratios (the correlation coefficient between these two variables is a mere $8.8 \%$ ).

\section{Measurement of Real Exchange Rate Exposure and Debt Deflation}

Key to our analysis is the definition and measurement of firms' RER exposure. This variable should tell us how firms' value changes in the event of a devaluation. However, this definition combines stock and flow effects that are crucial in the estimation of value. Regarding stocks, the RER exposure depends heavily on the liability side of the balance sheet, given that domestic firms typically hold non-tradable physical assets. However, it is in the flow dimension (related with the company's income statement) where the debt deflation effect is more deleterious, as dollarized firms with income only marginally correlated with the nominal exchange rate or, more generally, with income sensitive to fluctuations in the real exchange rate, are more likely to face a financial constraint that may limit its operations and eventually precipitate bankruptcy. ${ }^{12} \mathrm{On}$ the flow dimension, the real exchange rate exposure has to take into account not only the currency composition of debt (which determines the peso value of their financing expenses) but also the composition of its production mix. In light of this, we understand the real exchange rate exposure of a firm under a peg as the sensitivity of net income to changes in the real exchange rate.

Given the available data, we measure this exposure operationally combining debt composition and export orientation (under the realistic assumption that the dollar price of tradables is less sensitive to changes in the real exchange rate). The former is computed at firm level as the dollar-to-total debt (Dollar Ratio). For the latter, we compute the export content (measured as the export-to-value added ratio, or Expo) for the 33 sectors comprised in our database (at CIIU-2 digit level), and assign firms to these sectors according to their production mix. Thus, a firm will have a larger RER exposure the larger the dollar share of its debt, and the smaller the export component of its predominant sector. We also compute and use import content (Impo) in the same way. However, this variable should be treated with caution. First, a sector may use imported inputs that are purchased from retailers in the domestic market. Second, firms with high import-content inputs may compete with imported final products in the domestic market. Although they will be hit by the relative price adjustment that follows a devaluation, these firms may, at the same time, benefit from weaker competition from more expensive rival imports.

\footnotetext{
${ }^{12}$ As noted before, firms with tradable (but not traded) output may also suffer from imperfect dollar indexation, as domestic prices of tradables adjust to international ones only gradually.
} 
Debt deflation, in turn, is measured in two indirect ways. First, we follow the evolution of the real effective exchange rate $(R E R)$ during the period, as a proxy for exchange rate misalignments that are corrected over time through relative price adjustments. A fall in the RER would then be associated with the presence of debt deflation. Second, we use Deflator, computed as the price index of the sector normalized by the GDP deflator, to measure relative price movements across sectors of different degrees of tradability. Thus, a fall in this variable (alternatively, a negative change in the ratio between the sector and the aggregate price deflators) would be associated with an adverse relative price adjustment. This allows us not only to follow actual relative price changes but also to observe the extent to which adverse real exchange rate shocks are accommodated through nominal deflation. More precisely, we are able to test whether, in the event of a negative real shock, less tradable sectors are hit by a decline in relative prices.

Finally, devaluation expectations are proxied by the peso-dollar interest rate spread (from interbank lending rates). ${ }^{13}$ We also use RER (a signal of impending relative price adjustments) as an alternative. As noted, devaluation expectations are key to explain a differential response as a function of debt currency composition in a context in which expectations of an exchange rate devaluation may not materialize in practice.

\section{Hypotheses ${ }^{14}$}

\section{Capital Structure}

Under Convertibility, dollar and peso debt in Argentina only differed in that the former has higher risk and lower financing costs than the latter. A key question regarding the impact of financial dollarization is, then, which of these countervailing aspects dominated. More precisely, we hypothesize that:

H1: In the absence of (explicit or implicit) exchange rate guarantees, debt currency composition should reflect the currency composition of the debtor's income. Firms in sectors with a larger tradable component should display a larger dollar debt share.

Moreover, it was widely believed (as witness the presence of a persistent and highly volatile currency premium) that there was a positive probability of abandoning the currency board, which, in the absence of exchange rate guarantees, should have deterred non-tradable producers from dollarizing their funding sources. Thus, again in the absence of guarantees, an increase in devaluation expectations, as reflected in larger currency premiums, should have raised the risk associated with exchange rate exposure and moved (partially) unhedged (i.e., currency mismatched) debtors to reduce it. In this regard,

Hla: Absent (explicit or implicit) exchange rate guarantees, devaluation expectations should lead firms to reduce their real exchange rate exposure. The (positive) relationship between loan dollarization and the tradable component of the production mix of the debtor should strengthen as devaluation expectations increase.

\footnotetext{
${ }^{13}$ Our results are unaffected if alternatively we use the deposit rate (highly correlated, albeit less sensitive, than its interbank counterpart).

${ }^{14}$ Although we do not derive them from a formal model, these hypotheses, which encompass different ideas usually presented in policy and analytical discussions, are a useful guide to orient our empirical exploration.
} 
Finally, in the particular case of Argentina, there is an additional aspect that may have played a role in the currency composition of debt, namely, the fact that most privatized companies in regulated sectors were legally endowed an explicit exchange rate guarantee through indexation of their rates to the United States' Consumer Price Index. While the preservation of dollar indexation in the event of a sizeable devaluation may have been an unrealistic assumption, it could be argued that companies with dollarized prices should have mirror more closely the behavior of tradable producers. To check this in the data, we test whether hypotheses $\mathrm{H} 1$ and $\mathrm{H} 1$ a cease to hold for privatized companies with dollar-indexed prices.

\section{Real Exchange Rate Adjustment and Debt Deflation}

In the presence of (limited) nominal flexibility under a peg, an adverse external shock should have induced an accommodating relative price adjustment hitting non-tradable producers more than tradable producers. This is, in essence, the mechanism through which debt deflation materializes in practice. Accordingly, we expect that the real exchange rate misalignment that resulted from the successive adverse shocks that characterized the Argentine economy during the late 1990s should have reflected in a deterioration of the relative performance of non-tradable producers. In particular, we expect the RER adjustment to show in both relative price deflation and a fall in demand (sales), affecting the firm's returns and, through this channel, the investment performance. This prior leads to the following hypothesis:

H2: The impact of an RER adjustment through debt deflation on firm performance is positively correlated with the non-tradable component of the production mix of the debtor.

On the other hand, one could argue that, due to the presence of a persistent "peso problem," dollar debtors indeed benefited in good times from (sometimes substantially) lower financing costs, which eventually showed in a better performance and, through this channel, additional internal funds to finance new investment. ${ }^{15}$ Thus, once debt deflation is controlled for, a higher dollar debt ratio may be found to be positively (rather than negatively as conventional wisdom would indicate) correlated with firm's returns and investment. In line with this, we test the following:

H2a: In the absence of a nominal devaluation, debt dollarization is positively correlated with performance.

\section{Firms' Expectations and Anticipated Debt Deflation}

As noted, many of the existing studies on balance sheet effects assume that investment reacts expost to changes in the exchange rate. While this is true under a flexible regime where the exchange rate supposedly reflect all the information currently available, devaluation expectations under a peg may precede actual changes in the nominal exchange rate, thus inducing an anticipatory reaction in investments plans. Indeed, even if the negative expectations do not materialize, lack of confidence could induce firms to react, cutting investment plans preemptively. In either case, the probability of a devaluation (rather than shocks in fundamentals or even relative price adjustments) should be the key control variable.

\footnotetext{
${ }^{15}$ By good times we refer to the years in which devaluation expectations were not confirmed by real fundamentals and deflation was not already at play.
} 
H3: Investment was negatively correlated with devaluation expectations, the more so the higher the firms' real exchange rate exposure.

\section{Methodological Considerations}

\section{Estimation Methods}

We first consider estimation methods for the simple AR(1) model:

$$
y_{i t}=\alpha y_{i t-1}+\left(\mu_{i}+\varepsilon_{i t}\right) ;|\alpha|<1 ; \mathrm{i}=1, \ldots, \mathrm{N} ; \mathrm{t}=1, \ldots, \mathrm{T}
$$

where $\mu_{i}$ is an unobserved firm-specific time-invariant effect, and $\varepsilon_{i t}$ is a disturbance term independent across firms. The asymptotic analysis assumes that $\mathrm{T}$ is fixed. As it is well known, both the Ordinary Least Squares (OLS) and Least Square Dummy Variables (LSDV) estimators of $\alpha$ are inconsistent. Standard results for omitted variable bias indicate that, at least in large samples, the OLS estimator is biased upward and the LSDV estimator is biased downwards. The fact that these two estimators are likely to be biased in opposite directions is useful since a consistent estimator must lie between the OLS and the LSDV estimates, or at least not be significantly higher than the former or significantly lower than the latter (see Bond, 2002). We exploit this result in the ensuing analysis to check for the validity of our estimates.

An alternative method to eliminate $\mu_{i}$ consist in first differencing equation (1). Note, nonetheless, that, after differencing, $y_{i t-1}$ is correlated with the differenced equation error, $\Delta \varepsilon_{i t}$. Arellano and Bond (1991; AB) propose an efficient (among its class) linear estimator that is consistent even in panels with small and fixed T. They note that, as long as $\varepsilon_{i t}$ is serially uncorrelated, all lags of $y$ beyond $\mathrm{t}-1$ are valid instrument for the differenced equation in period $\mathrm{t}$. Consequently, a consistent estimator of the parameters of interest is obtained by using appropriately lagged variables as instruments. ${ }^{16}$

Generically, in this paper we adopt a dynamic specification for our empirical models and postulate dynamic two-way fixed effects error component models of the following general form:

$$
y_{i t}=\varphi y_{i t-1}-\beta(\mathrm{L}) x_{i t}+\lambda_{t}+\mu_{i}+\varepsilon_{i t}
$$

where $x_{i t}$ is a vector of covariates that varies both across firms and time (possible including interaction terms between aggregate and firm level variables), and where $\beta(\mathrm{L})$ is a lagpolynomial at most of order 1 .

\footnotetext{
${ }^{16}$ The consistency of the GMM estimator proposed by Arellano and Bond (1991) depends crucially on the absence of serial correlation in $\varepsilon_{i t}$. If the disturbance $\varepsilon_{i t}$ is not serially correlated, there should be evidence of significant negative first order serial correlation in the differenced residuals, but there should not be any evidence of second order serial correlation in the differenced residuals. Arellano and Bond (1991) develop tests for first and second order correlation in the differenced residuals. These tests are asymptotically standard normal distributed under the null hypothesis of no serial correlation. More generally, they propose to rely on Sargan tests of overidentifying restrictions to evaluate the specification of the estimated model. The Sargan test is asymptotically distributed Chisquared under the null hypothesis of no correlation among the instruments and the residuals of the transformed model.
} 
Different moment conditions will be available depending on what is assumed about the correlation between $x_{i t}$ and the components of the error term. We consider two cases here. First, let $x_{i t}$ to be strictly exogenous in the sense that is uncorrelated with all past, present and future realizations of $\varepsilon_{i t}$. However, in this case, we do not exploit the extra moment conditions available to instrument the lagged dependent variable in the transformed model. ${ }^{17}$ Second, let $x_{i t}$ to be endogenous in the sense that is correlated with present (and past) realizations of $\varepsilon_{i t}$ but is uncorrelated with all future realizations of the disturbance term. In this latter case, $x_{i t}$ is treated symmetrically with the dependent variable $y_{i t}$. Again, in this case, we do not exploit all the moment conditions available to instrument the endogenous $x$ 's regressors in the transformed model.

In what follows we report OLS, LSDV and AB estimates. We also report Sargan, AR(1) and AR(2) tests. All GMM estimates are optimal two-step ones (see Hansen, 1982). We always report corrected 2-step standard errors using Windmeijer (2000) finite sample correction methodology. ${ }^{18}$

\section{Econometric Specification}

Based on our baseline specification (1), the test of our capital structure hypotheses H1 and H1a on the effect of the currency composition of income on the currency composition of debt takes as dependent variable the dollar-to-total-debt ratio (Dollar Ratio) and includes as controls: lagged real sales (to control for firm size), year effects (to control for common macroeconomic factors), and firm effects (to control for firm-specific characteristics). In addition, we use the sector export share measures (Expo) to control for export orientation. ${ }^{19}$ Both dynamic and cross-section results will be reported. While the former would indicate how currency debt composition varies with changes in export content, these changes are likely to be small during the sample period. In particular, they display smaller variability over time than across firms. Thus, we expect any correlation between production mix and debt composition to be more visible using a cross section approach.

Both CRISK (currency risk) and RER (real effective exchange rate) are used to control for devaluation expectations. We expect non-export oriented firms to de-dollarize their liabilities as these expectations worsen. Hence, we interact the expectation variables with the export share to test whether the sensitivity of debt composition (if there is any) is correlated with the nontradable content of the firms' output mix.

To test for the impact of debt deflation on firm behavior (H2) we use two performance measures: the sales-to-assets ratio (Sales) and the earning-to-asset ratio (Earnings). In the regressions we control for time and fixed effects, and for the firm's leverage ratio (lagged). In addition, we use the Expo, RER, and CRISK, and their interactions. Finally, we include the sector deflators (Deflator) to tests the incidence of expectations, which may be traced to the incremental effect of currency risk on investment once relative price measures are controlled for.

\footnotetext{
${ }^{17}$ There is always a trade-off when applying an instrumental variable estimator. We want to obtain estimates that are as efficient as possible while avoiding small finite-sample bias.

${ }^{18}$ The standard two-step procedure would yield biased estimators of the standard errors in samples of our size.

${ }^{19} \mathrm{We}$ also include the lagged export share for robustness. Import shares (Impo), also tested, did not yield significant results and were omitted for brevity. All ommited results are available from the authors upon request.
} 
We expect a negative real shock to affect non-tradable producers both through quantities and prices. Thus, when Sales and, after controlling for the latter, Earnings are our dependent variables, we expect that the coefficient of the interaction of RER with Expo to be positive. In both cases, we also include Deflator to control for the incidence of relative price variations on earnings. Here, we expect the coefficient to be negative.

Note also that hypothesis $\mathrm{H} 2 \mathrm{a}$ would imply that, once other measures of price deflation are included, the coefficient corresponding to the dollar debt ratio would be positive in the performance regressions. Indeed, if investment reacts a posteriori to performance (for example, due to the access to internal funds of financially constrained firms), investment may also respond positively to dollar ratios in good times, given that dollar debt was, ex-post, less costly for Argentine firms during the period of analysis. We include Dollar Ratio (lagged) in the earnings regression to test this in the data.

Finally, we run regressions of (net) purchases of physical capital (Investment) on the previous set of controls, including both sales and earnings in the preceding period to test our $\mathrm{H} 3$ hypothesis on the effect of devaluation expectations on investment. We expect these coefficients to have a positive sign reflecting the incidence of the availability of internal funds.

\section{Empirical Results}

Tables 6 and 7 report the results on firms' debt composition and test our capital structure hypotheses. Tables 8 to 10 test the impact of real shocks on sales, earnings and investment in physical capital, as a function of the firms' export content and the evolution of relative prices, as well as the impact of devaluation expectations on investment.

Regarding the former, Tables 6 and 7 consistently show that the dollarization of corporate debt in convertible Argentina did not exhibit any relation with the tradable nature of the firms. There is no relationship either with the impending price adjustment as the RER fell during the last part of the decade. Table 6 presents a simple cross-section estimation of our baseline specification (including leverage ratio, firm size measured by assets, and export orientation as explanatory variables) using firm averages over the sample period. The results reveal a positive and significant association between the debt dollar ratio and both firm size and indebtedness. On the contrary, export orientation is negatively, albeit not significantly, related with debt dollarization, contradicting hypothesis $\mathrm{H} 1$ on the relationship between output and debt composition (column 2). As noted, many privatized companies were benefited by an explicit exchange rate guarantee in the form of dollar indexation of their tariffs. However, controlling for the presence of dollarized producers of services does not alter the results. Indeed, the coefficient for dollarized prices, while positive as expected, is not statistically significant (column 3).

Table 7 presents a fully specified dynamic model. We first present OLS and LSDV estimates of the parameters of interest as a check of the GMM estimates. As discussed in the previous section, consistent estimates of the coefficient of the dependent lagged variable must stretch out within the LSDV and OLS estimates. The GMM estimates we report exploit the 
moment conditions proposed by Arellano and Bond (1991) as explained in the previous section. $^{20}$

Coefficients differ as expected, with OLS closer to our cross-section estimates, and the coefficient of the lagged dependent variable estimated by AB lying between LSDV and OLS. We also report several specification tests. First, in all specifications, we test for the joint significance of the year effects. We also report the GMM estimates Sargan tests and the tests of first and second order autocorrelation of the transformed residuals as proposed in Arellano and Bond (1991). No sign of concern about the identification assumptions of the estimator used is reveled for any of these tests.

While the findings indicate that dollar ratios increase with leverage and size (possibly reflecting that firms need to reach a certain scale to gain access to the international capital markets), the evidence of a correlation between export orientation and debt dollarization is, at best, weak. The coefficient is positive in most of the specifications but barely significant only when estimated using fixed effects. In fact, once the model is consistently identified, by means of a GMM method (column 3), the sign of the Expo coefficient falls strongly suggesting the rejection of $\mathrm{H} 1{ }^{21}$ Note that we do not reject the hypothesis that the year effects are jointly equal to zero. In columns 4 and 5 we remove the year effects from the model and include the RER and CRISK measures. The estimated coefficients for these variables are not statistically significant. Since they do not span the same subspace that the year effects, we also test the exclusion restriction imposed. We do not reject it for any of the specifications reported.

It could be argued, however, that this specification biases our results towards lack of significance by bunching hedged exporters (for which currency risk should have been neutral) with unhedged non-tradable producers. To address this concern, in columns 6 to 9 we test whether the correlation between devaluation expectations and dollarization is stronger for the latter, interacting RER and CRISK with export orientation (similar results are obtained using the average export-content ratio over the period; see Galiani et al, 2003). Coefficients are positive as expected (with dollarization falling in relative terms with currency risk for firms with lower export orientation) but not significant. Again, none of the specification tests reported warns against our identification assumptions.

In sum, both hypotheses $\mathrm{H} 1$ and $\mathrm{H} 1 \mathrm{a}$ are rejected by the data. Debt dollarization appears to have been a widespread phenomenon that did not respond to export orientation (or, for that matter, price indexation), nor was the result of positive devaluation expectation, as it is attested by the lack of sensitivity, both in general and for real exchange rate-exposed firms in particular, to currency risk (which varied dramatically over the period). At any rate, these findings only confirm the intuition provided by our first glance at the data, which revealed very high levels of debt dollarization regardless of the sector of activity.

Tables 8 to 10 address the link between debt deflation and firm performance. As noted, in Table 8 we run regressions of the sales-to-asset ratio on the relative price deflator and the firm's export orientation. Again, results conform to econometric theory. In column (3), the Sargan test

\footnotetext{
${ }^{20}$ All available lags of the dependent variables are used as instruments. We also check the validity of these estimates by exploiting additional moment conditions as suggested in Blundell and Bond (1999). Results were always quite similar.

${ }^{21}$ The smaller coefficients obtained using using lagged values of Expo (ommited here for conciseness) further support this conclusion. See Galiani et al. (2003).
} 
suggests that at least one of the moment conditions exploited by the estimator used is rejected by the data at the 5 percent level. Thus, in column 4 we treat both expo and deflator as endogenous variables. Results, however, are almost identical. The deflator displays, as expected, a positive coefficient (with favorable relative price changes increasing income), significant in most specifications. Thus, this finding, combined with the fact that the evolution of relative prices during the period of analysis negatively affected non-export oriented firms (Table 4), provides support to the view that a deflationary adjustment to a more depreciated real exchange rate tended to burden primarily non-tradable producers.

Deflation, in turn, affects firm earnings through a decline in income, as shown in the models reported in Table 9. The deflator coefficient is positive and significant when introduced alone (column 3), but loses explanatory power once sales are controlled for (column 4). No direct effect from real exchange rate changes is detected beyond their impact on relative prices as reflected in the sector deflator. The dollar debt ratio allows us to test $\mathrm{H} 2 \mathrm{~b}$, namely, that a high dollar debt ratio in the preceding period, while ex-ante a one-sided bet for non-tradable producers exposed to RER changes, was profitable as long as a nominal devaluation did not materialize. Thus, debt dollarization may have enhanced, rather than hampered, firm performance through lower realized financing costs. The findings in Table 10 are consistent with this view. Larger dollar debt ratios are positively and significantly correlated with earnings in most specifications. 22

Table 10 moves on to test the impact on investment. While the results indicate that deflation did have an effect on investment performance through its effect on earnings, other controls do not have additional significant incidence. Our baseline specification controls for profits, which as expected, display a positive and, in some regressions, significant coefficient. On the other hand, deflator and the dollar ratio either fail to be significant or display the wrong sign.

Finally, columns 4 to 7 address hypothesis H3 about the effect of devaluation expectations on investment behavior. Given the degree of debt dollarization, an increase in the perceived probability of a nominal devaluation should lead to changes in investment that are positively correlated with the export content of the firm, with larger content associated with larger investment expansions. Hence, the interaction between the expectation variable and export content should be positive. In turn, given export orientation, devaluation expectations should lead to changes in investment that are negatively correlated with the level of debt dollarization, with larger dollar ratios associated with smaller investment expansions. Hence, the interaction between the expectations variable and the debt dollar share should be negative.

As the table shows, the results are mixed. On the one hand, the real exchange rate (our proxy for devaluation expectations) does not exhibit any significant differential effect across sectors with varying export orientations (indeed, it displays the wrong sign), in line with findings in the previous tables and contradicting H3. On the other, increases in currency risk do appear to have exerted a significantly negative effect on investment decisions by more financially dollarized firms (column 7).

One possible explanation for these findings points at the anticipation of a low initial passthrough even for producers of tradables that are partially sold in domestic markets, as the market substitution process induced by the change in relative prices takes time. If so, the distinction

\footnotetext{
${ }^{22}$ This results are in line with the higher profitability of dollar-indebted Asian corporations reported in Harvey and Roper (1999).
} 
tradable-nontradable would lead to an imperfect measure of the short-run real exchange rate exposure of the firm and, with a few exceptions (e.g. producers of traded commodities) devaluation expectations would impinge on the cash flows of all dollarized firms and, through this channel, on their investment plans. Note that this would reduce even further the scope for financial dollarization in a hedged environment. At any rate, this hypothesis deserves more careful empirical examination.

\section{Concluding Remarks}

Using the specific case of Argentina, this paper helps illuminate the implications of a pegged exchange rate regime in two different dimensions, namely, the relation between a peg and the capital structure of the firm, and the distribution of the adjustment to real shocks while the peg is in place. On the former, we found that debt dollarization was the rule rather than the exception, and it born no relationship to the firm's production mix or the ever-changing probability of a sudden nominal devaluation. While the actual presence of an implicit guarantee cannot be directly tested in the data, the results reported here are broadly consistent to the conventional view that non-tradable producers disregarded real exchange rate exposures even during periods of sizable currency risk.

Two comments are in order concerning the previous point. First, we are ignoring the behavior of the supply side of the credit market. In particular, there is some anecdotal evidence that, in Argentina, access to peso funding was limited, the more so the higher the currency risk. However, while this could explain the resilience of dollarization ratios to changes in expectations, it does not detract from the fact that a simple cross section shows a negative, albeit not significant, correlation between these ratios and export orientation that is not driven by exchange rate-protected privatized companies.

The impact of debt deflation, while weaker, is still visible in the data. Relative price changes, which, due to the protracted deflation that characterized the period under analysis, favored export-oriented firms, had the expected impact on sales and earnings and, through the latter, on investment. Moreover, there is some evidence that dollarized firms benefited from lower financing costs during the convertibility period. This finding is not trivial, as financial costs (combined with a wrong incentive design) appear to have been an important factor contributing to the reluctance of financial officers to hedge their exposures.

Finally, and in line with the result on the currency choice, increases in devaluation expectations did not elicit any differential response on investment from those firms more exposed to real exchange rate risk, either through a large debt dollarization ratio or through a limited export orientation.

In sum, the core results of the paper seem in line with two criticisms that the Argentine currency board received in recent years. First, that by fueling beliefs in an implicit guarantee it stimulated dollarization across the board, even in a context of varying and recurrently high devaluation expectations. Second, that while it could postpone the real exchange adjustment over time, it could not completely isolate the economy from real shocks: the feared balance sheet effects were replaced by less dramatic but equally deleterious debt deflation effects. 
Unfortunately, the discussion on balance sheet versus debt deflation effects is unlikely to be settled based on the Argentine case. On the one hand, the full impact of debt deflation cannot be assessed empirically because the devaluation interrupted what otherwise would have been a much longer contractionary process. On the other, after the devaluation, balance sheet effects materialized only to a very limited extent, as all domestic liabilities were compulsorily converted to the local currency at the exchange rate prevailing under the currency board. Nonetheless, the evidence presented here supports the concerns about the externalities associated with financial dollarization and the need to address the issue from a prudential perspective. Needless to say, the implication of any prudential norm requires an analysis of the supply side of the credit market, which would be the natural complement to the research presented in this paper. 


\section{References}

Aguiar, Mark. 2002. "Devaluation, Foreign Currency Exposure and Investment: the Case of Mexico", mimeo, University of Chicago.

Arellano, M., and Bond, S. 1991. "Some Tests of Specification for Panel Data: Monte Carlo Evidence and an Application to Employment Equations", Review of Economic Studies, 58, 277297.

Bekaert, Geert and Harvey, Campbell. 2003. "Chronology of Economic, Political and Financial Events in Emerging Markets - Argentina”, available at http://www.duke.edu/ charvey.

Bleakley, Hoyt and Cowan, Kevin. 2002. "Corporate Dollar Debt and Depreciations: Much Ado About Nothing?”, Federal Reserve Bank of Boston, Working Paper No. 02-5.

Blundell, R. and S. Bond. 1998. "Initial Conditions and Moment Restrictions in Dynamic Panel Data Models”, Journal of Econometrics, 87, 115-143.

Bond, S. 2002. "Dynamic Panel Data Models: A Guide to Micro Data Methods and Practice", Cemmap working paper CWP09/02.

Broda, Christian and Levy Yeyati, Eduardo. 2003. "Endogenous Deposit Dollarization," Staff Report 160, Federal Reserve Bank of New York.

Burnside, C., Eichenbaum, M., and Rebelo, S. 2001. "Hedging and Financial Fragility in Fixed Exchange Rate Regimes”, European Economic Review, 45(7), 1151-93.

Calvo, Guillermo. 2002. “The Case for Hard Pegs,” mimeo, University of Maryland.

Calvo, Guillermo and Reinhart, Carmen. 2002. "Fear of Floating," forthcoming, Quarterly Journal of Economics.

Campa, Jose Manuel, and Goldberg, Linda S. 1999. "Investment, Pass-Through, and the Exchange Rates: A Cross-Country Comparison", International Economic Review, Vol. 40 (2): 287-314.

De la Torre, Augusto, Levy Yeyati, Eduardo and Schmukler, Sergio. 2002. "Living or Dying with Hard Pegs: The Rise and Fall of Argentina's Currency Board," forthcoming, Economía.

Fisher, I. 1933. "The Debt-Deflation Theory of Great Depressions," Econometrica, 1 (4): $337-$ 357.

Forbes, Kristin J. 2002. "How Do Large Depreciations Affect Firm Performance?”, NBER Working Paper 9095.

Galiani, Sebastian, Gertler, Paul, Schargrodsky, Ernesto and Sturzenegger, Federico. 2002. "The Benefits and Costs of Privatization in Argentina: A Microeconomic Analysis," forthcoming in Chong, Alberto and Florencio Lopez-de-Silanes (eds.) The Benefits and Costs of Privatizations, Stanford University Press. 
Galiani, Sebastian, Levy Yeyati, Eduardo, and Schargrodsky, Ernesto. 2003. "Financial Dollarization and Debt Deflation under a Currency Board," Working Paper IDB, Research Department, Latin American Research Network

Gelos, R. Gaston. 2003. "Foreign Currency Debt in Emerging Markets: Firm-Level Evidence from Mexico", Economic Letters 78: 323-327.

Harvey, Campbell and Andrew Roper, 1999, "The Asian Bet," in Financial Markets and Development: The Crisis in Emerging Markets, Alison Harwood, Robert E. Litan, and Michael Pomerleano, eds., Brookings Institution Press, pp. 29-116.

Hausmann, Ricardo, Panizza, Ugo and Stein, Ernesto. 2001. "Why Do Countries Float the Way they Float?" Journal of Development Economics, 66: 387-414.

Hansen, Lars P. (1982), Large Sample Properties of Generalized Methods of Moments Estimators, Econometrica, 50, 1029-1054.

Ize, Alain, and Levy Yeyati, Eduardo. 2003. "Financial Dollarization", Journal of International Economics, 59: 323-347.

Levy Yeyati, Eduardo. 2001. "Diez Años de Convertibilidad: La Experiencia Argentina", Revista de Análisis Económico.

Levy Yeyati, Eduardo and Sturzenegger, Federico. 2002. "The Endogeneity of Exchange Rate Regimes," mimeo, Universidad Torcuato Di Tella, available at www.utdt.edu/ fsturzen.

Martinez, Lorenza, and Werner, Alejandro. 2002. "The Exchange Rate Regime and the Currency Composition of Corporate Debt: the Mexican Experience," Journal of Development Economics 69: 315-334.

Mercado, “Las 1000 empresas que más venden”, Agosto de 2001, Número 08, available online at www.mercado.com.ar

Nucci, Francesco, and Pozzolo, Alberto F. 2001. "Investment and the Exchange Rate: An Analysis with Firm-Level Panel Data", European Economic Review 45: 259-283.

Obstfeld, M. 2001. "Global Implications of Self oriented National Monetary Rules”, mimeo, UC Berkeley.

Windmeijer, Frank. 2000. "Criterion-Based Inference for GMM in Linear Dynamic Panel Data Models”, mimeo, Institute for Fiscal Studies, Nuffield College, Oxford University. 
Table 1. Argentina: Chronology of Major Economic and Political Events

\begin{tabular}{|c|c|}
\hline Date & Events \\
\hline 199103 & $\begin{array}{l}\text { Convertibility Law (fixed exchange rate to dollar and abolished all exchange and } \\
\text { capital controls). }\end{array}$ \\
\hline 199108 & Law protecting dollar denominated deposits enacted. \\
\hline 199110 & Decree ordering reform of the state, including deregulation of financial market. \\
\hline 199304 & Brady Plan agreement. \\
\hline 199307 & $\begin{array}{l}\text { Oil company (YPF) privatized as part of large privatization program. Second largest } \\
\text { equity offering by a developing country and one of the largest in the world. }\end{array}$ \\
\hline 199407 & New pension system began operating. \\
\hline 199412 & Mexican Tequila crisis. \\
\hline 199500 & $\begin{array}{l}\text { Banking crises: suspension of } 8 \text { banks and collapse of } 3 \text { banks. A limited system of } \\
\text { deposit insurance was introduced in response to the banking crisis. }\end{array}$ \\
\hline 199505 & Re-election of President Menem after constitutional reform. \\
\hline 199607 & Economy Minister Domingo Cavallo ousted. \\
\hline 199710 & Heavy selling in Hong Kong caused a domino effect in other emerging market. \\
\hline 199805 & Concern over the turmoil in Asian economies, financial problems in Russia. \\
\hline 199901 & Devaluation of the Brazilian real. \\
\hline 199905 & $\begin{array}{l}\text { Macroeconomic figures were weak. GDP contracted } 3.0 \% \text { and unemployment rose to } \\
14.5 \% \text {. Export to Brazil declined significantly. }\end{array}$ \\
\hline 199910 & $\begin{array}{l}\text { President de la Rua elected, ending President Carlos Menem's 10-year Peronist party } \\
\text { rule. }\end{array}$ \\
\hline 200010 & $\begin{array}{l}\text { Political crisis after allegations that a number of senators received bribes in exchange } \\
\text { for backing a labor reform. Vice President Alvarez resigned. The country failed to } \\
\text { meet its IMF-mandated fiscal targets due to slower third-quarter growth and high } \\
\text { interest rates. Spreads on its FRB Bonds increased to more than } 600 \text { basis points. }\end{array}$ \\
\hline 200011 & $\begin{array}{l}\text { S\&P lowered Argentina's local and foreign currency sovereign credit ratings. IMF-led } \\
\text { coalition announced a US } \$ 39.7 \text { billion aid package to prevent a debt crisis. }\end{array}$ \\
\hline 200012 & IMF bailout. \\
\hline 200103 & $\begin{array}{l}\text { Deteriorated fiscal situation forced two economy ministers to resign and Domingo } \\
\text { Cavallo took over as Economy Minister. }\end{array}$ \\
\hline 200106 & $\begin{array}{l}\text { A market-based solution was sought for the government's near inability to service debt } \\
\text { by swapping US } \$ 29.5 \text { billion of short-term obligations for long-term bonds. Beginning } \\
\text { of huge withdraws from the banking system. }\end{array}$ \\
\hline 200109 & US\$8 billion IMF bailout package failed to prevent double-digit drops in tax revenues. \\
\hline 200111 & $\begin{array}{l}\text { S\&P lowered Argentina's sovereign rating to default status. The government imposed } \\
\text { restrictions on deposit outflows and capital flight. }\end{array}$ \\
\hline 200112 & $\begin{array}{l}\text { Citizens protested the newly restructured government bonds and lack of access to bank } \\
\text { deposits. Mr. Cavallo and President de la Rua resigned. Three more interim leaders } \\
\text { followed before Eduardo Duhalde became president. End of Convertibility: debt } \\
\text { default and currency devaluation. }\end{array}$ \\
\hline
\end{tabular}

Source: Extracts from Bekaert and Harvey, Chronology of Economic, Political and Financial Events in Emerging Markets, available at http://www.duke.edu/ charvey 
Table 2. Panel Structure

\begin{tabular}{|c|c|c|c|c|c|c|c|c|c|c|c|}
\hline \multirow{2}{*}{ Firms } & \multirow{2}{*}{$\begin{array}{c}\text { Number } \\
\text { of } \\
\text { companies } \\
\end{array}$} & \multicolumn{10}{|c|}{ Number of observations } \\
\hline & & 1993 & 1994 & 1995 & 1996 & 1997 & 1998 & 1999 & 2000 & 2001 & TOTAL \\
\hline \multirow{4}{*}{$\begin{array}{l}\text { Always Private } \\
\text { Publicly Traded } \\
\text { Non-Publicly Traded }\end{array}$} & & & & & & & & & & & \\
\hline & 54 & 45 & 50 & 53 & 54 & 54 & 54 & 54 & 54 & 49 & 467 \\
\hline & 75 & 46 & 55 & 61 & 66 & 68 & 75 & 75 & 75 & 67 & 588 \\
\hline & 129 & 91 & 105 & 114 & 120 & 122 & 129 & 129 & 129 & 116 & 1055 \\
\hline \multicolumn{12}{|l|}{ Privatized } \\
\hline Publicly Traded & 17 & 11 & 13 & 15 & 16 & 17 & 17 & 17 & 17 & 17 & 140 \\
\hline \multirow{2}{*}{ Non-Publicly Traded } & 56 & 20 & 28 & 35 & 40 & 54 & 56 & 56 & 55 & 53 & 397 \\
\hline & 73 & 31 & 41 & 50 & 56 & 71 & 73 & 73 & 72 & 70 & 537 \\
\hline TOTAL & 202 & 122 & 146 & 164 & 176 & 193 & 202 & 202 & 201 & 186 & 1592 \\
\hline
\end{tabular}


Table 3. Tradable and Non-Tradable Companies

\begin{tabular}{lcccccccccccc}
\hline & \multirow{2}{*}{$\begin{array}{c}\text { Number } \\
\text { Firms companies }\end{array}$} & \multicolumn{10}{c}{ Number of observations } \\
\cline { 3 - 12 } & 1993 & 1994 & 1995 & 1996 & 1997 & 1998 & 1999 & 2000 & 2001 & TOTAL \\
\hline \multirow{2}{*}{$\begin{array}{l}\text { Tradable } \\
\text { Non-tradable }\end{array}$} & 104 & 78 & 89 & 93 & 98 & 98 & 104 & 104 & 104 & 96 & 864 \\
& 98 & 44 & 57 & 71 & 78 & 95 & 98 & 98 & 97 & 90 & 728 \\
\hline TOTAL & $\mathbf{2 0 2}$ & $\mathbf{1 2 2}$ & $\mathbf{1 4 6}$ & $\mathbf{1 6 4}$ & $\mathbf{1 7 6}$ & $\mathbf{1 9 3}$ & $\mathbf{2 0 2}$ & $\mathbf{2 0 2}$ & $\mathbf{2 0 1}$ & $\mathbf{1 8 6}$ & $\mathbf{1 5 9 2}$ \\
\hline
\end{tabular}

Note: A firm is classified as tradable if the export share (average of the ratio of exports over total added value over the period 1993-2001) of its sector of activity is larger than the median of the sector export shares across all the companies in our sample. 
Table 4. Summary Statistics

\begin{tabular}{lcc|cc}
\hline \multirow{2}{*}{ Variable } & \multicolumn{2}{c|}{ Tradables } & \multicolumn{2}{c}{ Non-Tradables } \\
\cline { 2 - 5 } & Mean & Median & Mean & Median \\
\hline & & & & \\
Total Debt* & $50.5 \%$ & $48.7 \%$ & $50.7 \%$ & $50.6 \%$ \\
Dollar Debt** & $55.1 \%$ & $62.0 \%$ & $57.9 \%$ & $64.4 \%$ \\
Log Assets & 18.84 & 18.89 & 18.99 & 19.06 \\
Investment in Physical Capital* & $4.0 \%$ & $2.6 \%$ & $8.0 \%$ & $4.1 \%$ \\
Purchases of Physical Capital* & $5.3 \%$ & $3.4 \%$ & $8.8 \%$ & $4.7 \%$ \\
Sales* & $88.9 \%$ & $73.8 \%$ & $85.9 \%$ & $55.7 \%$ \\
Earnings* & $9.3 \%$ & $7.1 \%$ & $15.7 \%$ & $11.4 \%$ \\
Expo Share & $42.7 \%$ & $32.6 \%$ & $0.5 \%$ & $0.02 \%$ \\
Impo Share & $115.0 \%$ & $35.0 \%$ & $1.6 \%$ & $0.03 \%$ \\
Deflator (interperiod variation) & $-0.9 \%$ & $-0.4 \%$ & $-10.8 \%$ & $-21.6 \%$ \\
& & & & \\
\hline
\end{tabular}

Notes: A firm is classified as tradable if the expo share (1993-2001 average of the ratio of exports over total added value) of its sector of activity is larger than the median of the sector export shares across all the companies in our sample. * Ratios over total assets. ** Ratios over total debt 
Table 5. Summary Statistics by Sector of Economic Activity

\begin{tabular}{|c|c|c|c|c|c|c|c|c|c|c|c|c|}
\hline Firms & CIIU & Sector Description & $\begin{array}{l}\text { Total } \\
\text { Debt* }\end{array}$ & $\begin{array}{l}\text { Dollar } \\
\text { Debt } * *\end{array}$ & $\begin{array}{c}\text { Log } \\
\text { Assets }\end{array}$ & $\begin{array}{c}\text { Investment } \\
\text { in Physical } \\
\text { Capital* }\end{array}$ & $\begin{array}{l}\text { Purchases } \\
\text { of physical } \\
\text { capital* }\end{array}$ & Sales* & Earnings* & $\begin{array}{c}\text { Expo } \\
\text { Share }^{1} \\
\end{array}$ & $\begin{array}{c}\text { Impo } \\
\text { Share }^{2} \\
\end{array}$ & $\begin{array}{c}\text { Deflator } \\
\text { (interperiod }^{\text {variation) }}\end{array}$ \\
\hline & & Tradable Sectors & & & & & & & & & & \\
\hline 2 & 30 & Computer Equipments & $82.7 \%$ & $89.4 \%$ & 18.7 & $11.4 \%$ & $2649.0 \%$ & $102.7 \%$ & $9.4 \%$ & $129.9 \%$ & $16.6 \%$ & $-48.6 \%$ \\
\hline 8 & 34 & Automobile & $68.6 \%$ & $59.9 \%$ & 19.7 & $5.6 \%$ & $135.9 \%$ & $113.5 \%$ & $6.3 \%$ & $83.1 \%$ & $6.0 \%$ & $-7.8 \%$ \\
\hline 2 & 19 & Leather & $62.0 \%$ & $60.3 \%$ & 18.8 & $-2.4 \%$ & $19.6 \%$ & $56.6 \%$ & $6.0 \%$ & $76.2 \%$ & $2.4 \%$ & $0.7 \%$ \\
\hline 21 & 15 & Food and Beverage & $50.3 \%$ & $50.2 \%$ & 19.1 & $5.0 \%$ & $8.9 \%$ & $104.9 \%$ & $12.7 \%$ & $68.4 \%$ & $6.2 \%$ & $-0.4 \%$ \\
\hline 3 & 27 & Metals & $40.3 \%$ & $63.1 \%$ & 20.3 & $4.2 \%$ & $55.7 \%$ & $66.4 \%$ & $9.1 \%$ & $64.7 \%$ & $4.5 \%$ & $-7.8 \%$ \\
\hline 2 & 16 & Tobacco & $44.1 \%$ & $12.7 \%$ & 19.5 & $4.4 \%$ & $6.4 \%$ & $104.8 \%$ & $22.5 \%$ & $49.0 \%$ & $5.9 \%$ & $6.5 \%$ \\
\hline 9 & 11 & Oil and Gas & $54.5 \%$ & $71.4 \%$ & 20.6 & $7.8 \%$ & $3.6 \%$ & $40.4 \%$ & $15.1 \%$ & $38.6 \%$ & $9.8 \%$ & $31.0 \%$ \\
\hline 8 & 1 & Agriculture and Livestock & $66.3 \%$ & $73.5 \%$ & 18.6 & $2.7 \%$ & $3.6 \%$ & $158.0 \%$ & $7.8 \%$ & $30.5 \%$ & $3.7 \%$ & $-22.4 \%$ \\
\hline 17 & 24 & Chemicals & $51.9 \%$ & $49.8 \%$ & 18.4 & $3.1 \%$ & $76.7 \%$ & $110.1 \%$ & $10.6 \%$ & $28.5 \%$ & $4.2 \%$ & $12.2 \%$ \\
\hline 1 & 31 & Electrical Equipments & $21.5 \%$ & $27.2 \%$ & 15.1 & $0.4 \%$ & $177.9 \%$ & $75.0 \%$ & $4.6 \%$ & $28.0 \%$ & $0.4 \%$ & $-19.9 \%$ \\
\hline 2 & 17 & Textile & $31.6 \%$ & $64.5 \%$ & 17.1 & $4.7 \%$ & $34.5 \%$ & $61.1 \%$ & $7.0 \%$ & $24.9 \%$ & $6.1 \%$ & $-11.7 \%$ \\
\hline 6 & 29 & Other Machinery & $31.7 \%$ & $30.0 \%$ & 16.7 & $-0.1 \%$ & $157.5 \%$ & $50.4 \%$ & $0.0 \%$ & $24.3 \%$ & $1.5 \%$ & $-5.1 \%$ \\
\hline 8 & 21 & Paper & $35.9 \%$ & $38.3 \%$ & 18.9 & $2.1 \%$ & $59.0 \%$ & $41.9 \%$ & $5.7 \%$ & $18.1 \%$ & $2.7 \%$ & $2.4 \%$ \\
\hline 1 & 2 & Wood Extraction & $22.2 \%$ & $55.5 \%$ & 17.3 & $-3.8 \%$ & $2.3 \%$ & $18.1 \%$ & $-1.1 \%$ & $15.7 \%$ & $1.3 \%$ & $-16.9 \%$ \\
\hline 3 & 32 & Radio and Television Equipments & $81.5 \%$ & $79.1 \%$ & 17.4 & $6.1 \%$ & $428.4 \%$ & $112.6 \%$ & $2.8 \%$ & $15.6 \%$ & $7.7 \%$ & $-48.6 \%$ \\
\hline 3 & 25 & Rubber, Plastics & $47.0 \%$ & $69.3 \%$ & 18.1 & $6.1 \%$ & $36.3 \%$ & $88.0 \%$ & $10.5 \%$ & $10.7 \%$ & $7.3 \%$ & $14.0 \%$ \\
\hline 2 & 28 & Metal Products & $30.1 \%$ & $63.9 \%$ & 21.1 & $3.5 \%$ & $39.4 \%$ & $53.6 \%$ & $9.8 \%$ & $8.3 \%$ & $4.0 \%$ & $-0.9 \%$ \\
\hline \multirow[t]{2}{*}{6} & 26 & Mineral non metallic & $34.7 \%$ & $56.7 \%$ & 18.8 & $4.5 \%$ & $22.5 \%$ & $48.5 \%$ & $8.4 \%$ & $8.3 \%$ & $5.0 \%$ & $-8.1 \%$ \\
\hline & & Non-Tradable Sectors & & & & & & & & & & \\
\hline 1 & 20 & Wood products & $37.4 \%$ & $58.0 \%$ & 17.9 & $3.7 \%$ & $11.2 \%$ & $48.2 \%$ & $8.7 \%$ & $4.9 \%$ & $6.9 \%$ & $-9.1 \%$ \\
\hline 47 & 40 & Gas, Electricity, Steam and Water supply & $37.6 \%$ & $66.2 \%$ & 19.2 & $6.8 \%$ & $2.7 \%$ & $41.3 \%$ & $10.6 \%$ & $0.8 \%$ & $7.3 \%$ & $-21.6 \%$ \\
\hline 2 & 92 & Sporting and Cultural Activities & $60.3 \%$ & $64.3 \%$ & 18.3 & $6.9 \%$ & $0.1 \%$ & $64.1 \%$ & $14.7 \%$ & $0.2 \%$ & $7.0 \%$ & $-20.3 \%$ \\
\hline 1 & 41 & Water Distribution & $70.1 \%$ & $75.8 \%$ & 20.6 & $23.8 \%$ & $0 \%$ & $49.2 \%$ & $18.5 \%$ & $0 \%$ & $23.9 \%$ & $24.2 \%$ \\
\hline 5 & 45 & Construction & $49.8 \%$ & $43.6 \%$ & 18.0 & $2.7 \%$ & $0 \%$ & $65.9 \%$ & $8.7 \%$ & $0 \%$ & $3.7 \%$ & $-9.8 \%$ \\
\hline 2 & 50 & Car sale, manteinance and reparation & $45.9 \%$ & $72.5 \%$ & 20.9 & $6.6 \%$ & $0 \%$ & $91.2 \%$ & $9.9 \%$ & $0 \%$ & $8.5 \%$ & $-8.6 \%$ \\
\hline 3 & 51 & Wholesale & $61.9 \%$ & $43.0 \%$ & 17.9 & $3.4 \%$ & $0 \%$ & $307.2 \%$ & $9.2 \%$ & $0 \%$ & $4.1 \%$ & $-2.9 \%$ \\
\hline 7 & 52 & Retailing & $62.0 \%$ & $42.9 \%$ & 19.1 & $16.0 \%$ & $0 \%$ & $179.7 \%$ & $7.3 \%$ & $0 \%$ & $17.8 \%$ & $-3.5 \%$ \\
\hline 11 & 60 & Road Transport & $71.4 \%$ & $36.3 \%$ & 17.6 & $10.5 \%$ & $0 \%$ & $117.1 \%$ & $55.6 \%$ & $0 \%$ & $11.3 \%$ & $20.3 \%$ \\
\hline 2 & 62 & Air Transport & $87.4 \%$ & $70.2 \%$ & 19.2 & $16.0 \%$ & $0 \%$ & $113.0 \%$ & $2.3 \%$ & $0 \%$ & $21.9 \%$ & $34.0 \%$ \\
\hline 2 & 63 & Travel Agency & $70.1 \%$ & $61.6 \%$ & 20.1 & $8.2 \%$ & $0 \%$ & $27.8 \%$ & $6.4 \%$ & $0 \%$ & $8.2 \%$ & $38.1 \%$ \\
\hline 10 & 64 & Post Offices and Telecommunications & $59.0 \%$ & $66.1 \%$ & 20.5 & $8.1 \%$ & $0 \%$ & $60.2 \%$ & $14.9 \%$ & $0 \%$ & $8.8 \%$ & $-28.4 \%$ \\
\hline 1 & 65 & Real Estate and Financial Services & $25.7 \%$ & $91.2 \%$ & 19.7 & $0.5 \%$ & $0 \%$ & $12.3 \%$ & $3.3 \%$ & $0 \%$ & $0.7 \%$ & $-15.1 \%$ \\
\hline 1 & 70 & Real Estate & $45.1 \%$ & $80.5 \%$ & 19.1 & $13.5 \%$ & $0 \%$ & $7.1 \%$ & $3.9 \%$ & $0 \%$ & $13.6 \%$ & $7.5 \%$ \\
\hline 3 & 85 & Health and Social Services & $75.9 \%$ & $17.2 \%$ & 17.4 & $2.1 \%$ & $0 \%$ & $429.8 \%$ & $3.6 \%$ & $0 \%$ & $2.6 \%$ & $2.1 \%$ \\
\hline
\end{tabular}

Notes: * Ratios over total assets / ** Ratios over total debt. 1 Ratio exports/value added for each sector / 2 Ratio imports/value added for each sector / 3 Variation over 1993-2001. 
Table 6. Dependent Variable: Dollar Ratio (cross section)

\begin{tabular}{|c|c|c|c|}
\hline $\begin{array}{c}\text { Explanatory } \\
\text { Variables }\end{array}$ & $\begin{array}{c}\text { Coefficients } \\
\text { (Std. Errors) } \\
(\mathbf{1})\end{array}$ & $\begin{array}{c}\text { Coefficients } \\
\text { (Std. Errors) } \\
\mathbf{( 2 )}\end{array}$ & $\begin{array}{c}\text { Coefficients } \\
\text { (Std. Errors) } \\
(\mathbf{3})\end{array}$ \\
\hline Leverage Ratio & $0.273^{* * *}$ & $0.288^{* * *}$ & $0.293^{* * *}$ \\
& $(0.076)$ & $(0.077)$ & $(0.078)$ \\
\hline \multirow{2}{*}{ Log Assets } & $0.081 * * *$ & $0.082 * * *$ & $0.081^{* * *}$ \\
& $(0.011)$ & $(0.011)$ & $(0.011)$ \\
\hline Expo & & -0.072 & -0.065 \\
& & $(0.055)$ & $(0.059)$ \\
\hline Dollar Indexation & & & 0.018 \\
& & $20.049)$ \\
\hline Number of & 202 & & 202 \\
\hline Observations & & 202 & \\
\hline
\end{tabular}

Notes: Standard errors are reported in parentheses. *** Statistically different from zero at the 0.01 level of significance. ** Statistically different from zero at the 0.05 level of significance. * Statistically different from zero at the 0.1 level of significance. 
Table 7. Dependent Variable: Dollar Ratio

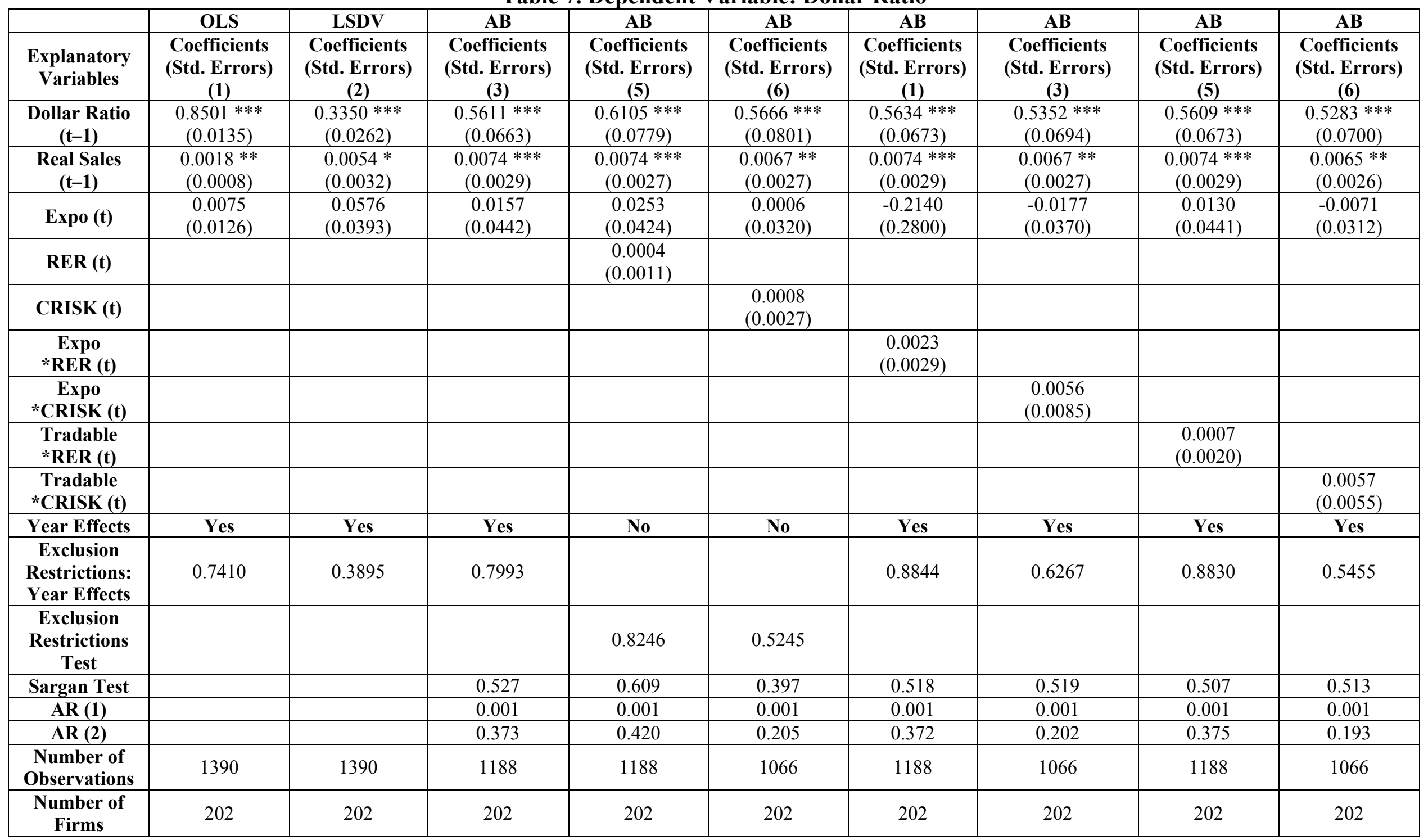

Notes: Asymptotic standard errors robust to general cross-section and time series heteroskedasticity are reported in parentheses. The GMM estimates are all twostep estimates. The values of the coefficient and standard errors for Real Sales are multiplied by 100,000,000. Standard errors are corrected for finite sample bias following Windmeijer (2002). For the Sargan, AR(1) and AR(2) tests, the statistic reported is the p-value. *** Statistically different from zero at the 0.01 level of significance. $* *$ Statistically different from zero at the 0.05 level of significance. $*$ Statistically different from zero at the 0.1 level of significance. 
Table 8. Dependent Variable: Sales Ratio

\begin{tabular}{|c|c|c|c|c|}
\hline & OLS & LSDV & $\mathbf{A B}$ & $\mathbf{A B}$ \\
\hline Explanatory Variables & $\begin{array}{c}\text { Coefficients } \\
\text { (Std. Errors) } \\
\text { (1) }\end{array}$ & $\begin{array}{c}\text { Coefficients } \\
\text { (Std. Errors) } \\
\text { (2) }\end{array}$ & $\begin{array}{c}\text { Coefficients } \\
\text { (Std. Errors) } \\
\text { (3) }\end{array}$ & $\begin{array}{c}\text { Coefficients } \\
\text { (Std. Errors) } \\
\text { (4) }\end{array}$ \\
\hline Sales Ratio (t-1) & $\begin{array}{c}0.8440 * * * \\
(0.0086)\end{array}$ & $\begin{array}{c}0.4613 * * * \\
(0.0222) \\
\end{array}$ & $\begin{array}{c}0.5939 * * * \\
(0.1637) \\
\end{array}$ & $\begin{array}{c}0.5863 * * * \\
(0.1738) \\
\end{array}$ \\
\hline $\operatorname{Expo}(t)$ & $\begin{array}{l}-0.0048 \\
(0.0259)\end{array}$ & $\begin{array}{l}-0.0308 \\
(0.0829)\end{array}$ & $\begin{array}{l}-0.0367 \\
(0.1011)\end{array}$ & $\begin{array}{l}-0.1654 \\
(0.4610)\end{array}$ \\
\hline Deflator (t) & $\begin{array}{c}0.0831 \\
(0.0629)\end{array}$ & $\begin{array}{c}0.0238 \\
(0.1254)\end{array}$ & $\begin{array}{c}0.2875 * * \\
(0.1337)\end{array}$ & $\begin{array}{l}0.3290^{*} \\
(0.2024)\end{array}$ \\
\hline Year Effects & Yes & Yes & Yes & Yes \\
\hline $\begin{array}{c}\text { Exclusion Restrictions: } \\
\text { Year Effects }\end{array}$ & 0.0001 & 0.0000 & 0.0001 & 0.0114 \\
\hline Sargan Test & & & 0.038 & 0.165 \\
\hline AR (1) & & & 0.007 & 0.009 \\
\hline AR (2) & & & 0.869 & 0.873 \\
\hline Number of Observations & 1390 & 1390 & 1188 & 1188 \\
\hline Number of Firms & 202 & 202 & 202 & 202 \\
\hline
\end{tabular}

Notes: Asymptotic standard errors robust to general cross-section and time series heteroskedasticity are reported in parentheses. The GMM estimates are all two-step estimates. Standard errors are corrected for finite sample bias following Windmeijer (2002). For the Sargan, AR(1) and AR(2) tests, the statistic reported is the p-value. *** Statistically different from zero at the 0.01 level of significance. ** Statistically different from zero at the 0.05 level of significance. * Statistically different from zero at the 0.1 level of significance. 
Table 9. Dependent Variable: Earnings Ratio

\begin{tabular}{|c|c|c|c|c|c|}
\hline & OLS & LSDV & AB & AB & AB \\
\hline Explanatory Variables & $\begin{array}{c}\text { Coefficients } \\
\text { (Std. Errors) } \\
\text { (1) }\end{array}$ & $\begin{array}{c}\text { Coefficients } \\
\text { (Std. Errors) } \\
(2) \\
\end{array}$ & $\begin{array}{c}\text { Coefficients } \\
\text { (Std. Errors) } \\
(3) \\
\end{array}$ & $\begin{array}{c}\text { Coefficients } \\
\text { (Std. Errors) } \\
(4) \\
\end{array}$ & $\begin{array}{c}\text { Coefficients } \\
\text { (Std. Errors) } \\
\text { (5) }\end{array}$ \\
\hline Earnings Ratio (t - 1$)$ & $\begin{array}{c}0.8000 * * * \\
(0.0141)\end{array}$ & $\begin{array}{c}0.4341 * * * \\
(0.0264)\end{array}$ & $\begin{array}{c}0.6822 * * * \\
(0.0950)\end{array}$ & $\begin{array}{c}0.5099 * * * \\
(0.1011)\end{array}$ & $\begin{array}{c}0.5077 * * * \\
(0.1032) \\
\end{array}$ \\
\hline Leverage Ratio (t-1) & $\begin{array}{c}0.0071 \\
(0.0114) \\
\end{array}$ & $\begin{array}{l}-0.0233 \\
(0.0213)\end{array}$ & $\begin{array}{c}0.0345 \\
(0.0390) \\
\end{array}$ & $\begin{array}{c}0.0060 \\
(0.0350) \\
\end{array}$ & $\begin{array}{c}0.0061 \\
(0.0351)\end{array}$ \\
\hline Dollar Ratio (t-1) & $\begin{array}{c}0.0038 \\
(0.0094) \\
\end{array}$ & $\begin{array}{c}0.0273 \\
(0.0186) \\
\end{array}$ & $\begin{array}{c}0.0575 * * * \\
(0.0205)\end{array}$ & $\begin{array}{c}0.0366 * * \\
(0.0183) \\
\end{array}$ & $\begin{array}{c}0.0365 * * \\
(0.0183) \\
\end{array}$ \\
\hline $\operatorname{Expo}(t)$ & $\begin{array}{c}-0.0145 * \\
(0.0083)\end{array}$ & $\begin{array}{c}0.0224 \\
(0.0271)\end{array}$ & $\begin{array}{l}-0.0484 \\
(0.0393)\end{array}$ & $\begin{array}{l}-0.0234 \\
(0.0289)\end{array}$ & $\begin{array}{c}0.0142 \\
(0.1837)\end{array}$ \\
\hline Deflator (t) & $\begin{array}{c}0.0230 \\
(0.0205) \\
\end{array}$ & $\begin{array}{l}-0.0289 \\
(0.0412)\end{array}$ & $\begin{array}{c}0.0989 * * \\
(0.0475) \\
\end{array}$ & $\begin{array}{c}0.0609 \\
(0.0407) \\
\end{array}$ & $\begin{array}{c}0.0612 \\
(0.0403) \\
\end{array}$ \\
\hline Sales Ratio (t) & & & & $\begin{array}{l}0.1330 * * * \\
(0.0434)\end{array}$ & $\begin{array}{c}0.1333 * * * \\
(0.0426)\end{array}$ \\
\hline $\operatorname{Expo} * \mathbf{R E R}(\mathbf{t})$ & & & & & $\begin{array}{l}-0.0004 \\
(0.0020)\end{array}$ \\
\hline Year Effects & Yes & Yes & Yes & Yes & Yes \\
\hline $\begin{array}{c}\text { Exclusion Restrictions: } \\
\text { Year Effects }\end{array}$ & 0.0002 & 0.0001 & 0.0001 & 0.0009 & 0.0015 \\
\hline Sargan Test & & & 0.209 & 0.220 & 0.203 \\
\hline AR (1) & & & 0.001 & 0.003 & 0.003 \\
\hline AR (2) & & & 0.621 & 0.142 & 0.140 \\
\hline Number of Observations & 1390 & 1390 & 1188 & 1188 & 1188 \\
\hline Number of Firms & 202 & 202 & 202 & 202 & 202 \\
\hline
\end{tabular}

Notes: Asymptotic standard errors robust to general cross-section and time series heteroskedasticity are reported in parentheses. The GMM estimates are all two-step estimates. Standard errors are corrected for finite sample bias following Windmeijer (2002). For the Sargan, AR(1) and AR(2) tests, the statistic reported is the p-value. *** Statistically different from zero at the 0.01 level of significance. ** Statistically different from zero at the 0.05 level of significance. * Statistically different from zero at the 0.1 level of significance. 
Table 10. Dependent Variable: Investment Ratio

\begin{tabular}{|c|c|c|c|c|c|c|c|}
\hline & OLS & LSDV & $\mathbf{A B}$ & $\mathbf{A B}$ & $\mathbf{A B}$ & $\mathbf{A B}$ & $\mathbf{A B}$ \\
\hline Explanatory Variables & $\begin{array}{c}\text { Coefficients } \\
\text { (Std. Errors) } \\
(1)\end{array}$ & $\begin{array}{c}\text { Coefficients } \\
\text { (Std. Errors) } \\
(2) \\
\end{array}$ & $\begin{array}{c}\text { Coefficients } \\
\text { (Std. Errors) } \\
(3) \\
\end{array}$ & $\begin{array}{c}\text { Coefficients } \\
\text { (Std. Errors) } \\
(4) \\
\end{array}$ & $\begin{array}{c}\text { Coefficients } \\
\text { (Std. Errors) } \\
\text { (3) } \\
\end{array}$ & $\begin{array}{c}\text { Coefficients } \\
\text { (Std. Errors) } \\
(5)\end{array}$ & $\begin{array}{c}\text { Coefficients } \\
\text { (Std. Errors) } \\
(6) \\
\end{array}$ \\
\hline Investment Ratio $(t-1)$ & $\begin{array}{c}0.3389 * * * \\
(0.0201) \\
\end{array}$ & $\begin{array}{c}0.0488 * * \\
(0.0230)\end{array}$ & $\begin{array}{c}0.2353 * * * \\
(0.0558) \\
\end{array}$ & $\begin{array}{c}0.2362 * * * \\
(0.0556) \\
\end{array}$ & $\begin{array}{c}0.2213 * * * \\
(0.0631) \\
\end{array}$ & $\begin{array}{c}0.2221 * * * \\
(0.0597) \\
\end{array}$ & $\begin{array}{c}0.2317 * * * \\
(0.0563)\end{array}$ \\
\hline Leverage Ratio (t-1) & $\begin{array}{c}0.0258 * * * \\
(0.0092)\end{array}$ & $\begin{array}{c}0.0681 * * * \\
(0.0160)\end{array}$ & $\begin{array}{c}0.0709 \\
(0.0511)\end{array}$ & $\begin{array}{c}0.0698 \\
(0.0507) \\
\end{array}$ & $\begin{array}{c}0.0795 \\
(0.0594)\end{array}$ & $\begin{array}{c}0.0996 \\
(0.0719)\end{array}$ & $\begin{array}{c}0.0839 \\
(0.0833)\end{array}$ \\
\hline Dollar Ratio (t-1) & $\begin{array}{l}-0.0029 \\
(0.0076)\end{array}$ & $\begin{array}{c}-0.0395 * * * \\
(0.0140)\end{array}$ & $\begin{array}{c}-0.0704 * * \\
(0.0338) \\
\end{array}$ & $\begin{array}{c}-0.0701 * * \\
(0.0334) \\
\end{array}$ & $\begin{array}{c}-0.0715 * \\
(0.0371) \\
\end{array}$ & $\begin{array}{r}1.2236 \\
(1.074) \\
\end{array}$ & $\begin{array}{l}-0.0050 \\
(0.0409) \\
\end{array}$ \\
\hline Earnings Ratio (t-1) & $\begin{array}{c}0.0528 * * * \\
(0.0114)\end{array}$ & $\begin{array}{c}0.0506 * * \\
(0.0198)\end{array}$ & $\begin{array}{l}0.0450 * \\
(0.0258)\end{array}$ & $\begin{array}{c}0.0429 \\
(0.0262)\end{array}$ & $\begin{array}{c}0.0572 * * \\
(0.0271)\end{array}$ & $\begin{array}{l}0.0467 * \\
(0.0260)\end{array}$ & $\begin{array}{c}0.0659 * * * \\
(0.0238)\end{array}$ \\
\hline $\operatorname{Expo}(t)$ & $\begin{array}{l}-0.0140 * * \\
(0.0067)\end{array}$ & $\begin{array}{c}0.0187 \\
(0.0203)\end{array}$ & $\begin{array}{l}-0.0088 \\
(0.0164)\end{array}$ & $\begin{array}{c}0.0443 \\
(0.1791)\end{array}$ & $\begin{array}{l}-0.0086 \\
(0.0206)\end{array}$ & $\begin{array}{c}0.0028 \\
(0.0180)\end{array}$ & $\begin{array}{l}-0.0077 \\
(0.0164)\end{array}$ \\
\hline Deflator (t) & $\begin{array}{c}0.0112 \\
(0.0164) \\
\end{array}$ & $\begin{array}{l}-0.0283 \\
(0.0308) \\
\end{array}$ & $\begin{array}{l}-0.0559 \\
(0.0648)\end{array}$ & $\begin{array}{l}-0.0554 \\
(0.0643)\end{array}$ & $\begin{array}{l}-0.0846 \\
(0.0742) \\
\end{array}$ & $\begin{array}{l}-0.0410 \\
(0.0620)\end{array}$ & $\begin{array}{c}-0.1540 * * \\
(0.0740)\end{array}$ \\
\hline Expo*RER (t) & & & & $\begin{array}{l}-0.0005 \\
(0.0018)\end{array}$ & & & \\
\hline $\operatorname{Expo} * \operatorname{CRISK}(t)$ & & & & & $\begin{array}{l}-0.0012 \\
(0.0031) \\
\end{array}$ & & \\
\hline $\begin{array}{c}\text { Dollar Ratio (t }-1) \\
\text { *RER (t) }\end{array}$ & & & & & & $\begin{array}{l}-0.0136 \\
(0.0114)\end{array}$ & \\
\hline $\begin{array}{c}\text { Dollar Ratio (t -1) } \\
\text { *CRISK (t) }\end{array}$ & & & & & & & $\begin{array}{c}-0.0454 * * \\
(0.0188)\end{array}$ \\
\hline Year Effects & Yes & Yes & Yes & Yes & Yes & Yes & Yes \\
\hline $\begin{array}{c}\text { Exclusion Restrictions: } \\
\text { Year Effects }\end{array}$ & 0.0003 & 0.0001 & 0.2125 & 0.2586 & 0.2534 & 0.2290 & 0.0360 \\
\hline Sargan Test & $\ldots \ldots$ & $\ldots \ldots$ & 0.126 & 0.115 & 0.147 & 0.150 & 0.518 \\
\hline AR (1) & $\ldots$ & $\ldots \ldots$ & 0.001 & 0.001 & 0.001 & 0.001 & 0.001 \\
\hline AR (2) & $\ldots$ & $\ldots \ldots$ & 0.514 & 0.517 & 0.204 & 0.277 & 0.390 \\
\hline Number of Observations & 1390 & 1390 & 1188 & 1188 & 1066 & 1188 & 1066 \\
\hline Number of Firms & 202 & 202 & 202 & 202 & 202 & 202 & 202 \\
\hline
\end{tabular}

Notes: Asymptotic standard errors robust to general cross-section and time series heteroskedasticity are reported in parentheses. The GMM estimates are all two-step estimates. Standard errors are corrected for finite sample bias following Windmeijer (2002). For the Sargan, AR(1) and AR(2) tests, the statistic reported is the p-value. *** Statistically different from zero at the 0.01 level of significance. $* *$ Statistically different from zero at the 0.05 level of significance. $*$ Statistically different from zero at the 0.1 level of significance. 


\section{APPENDIX 1: Argentina's Macroeconomic Variables}
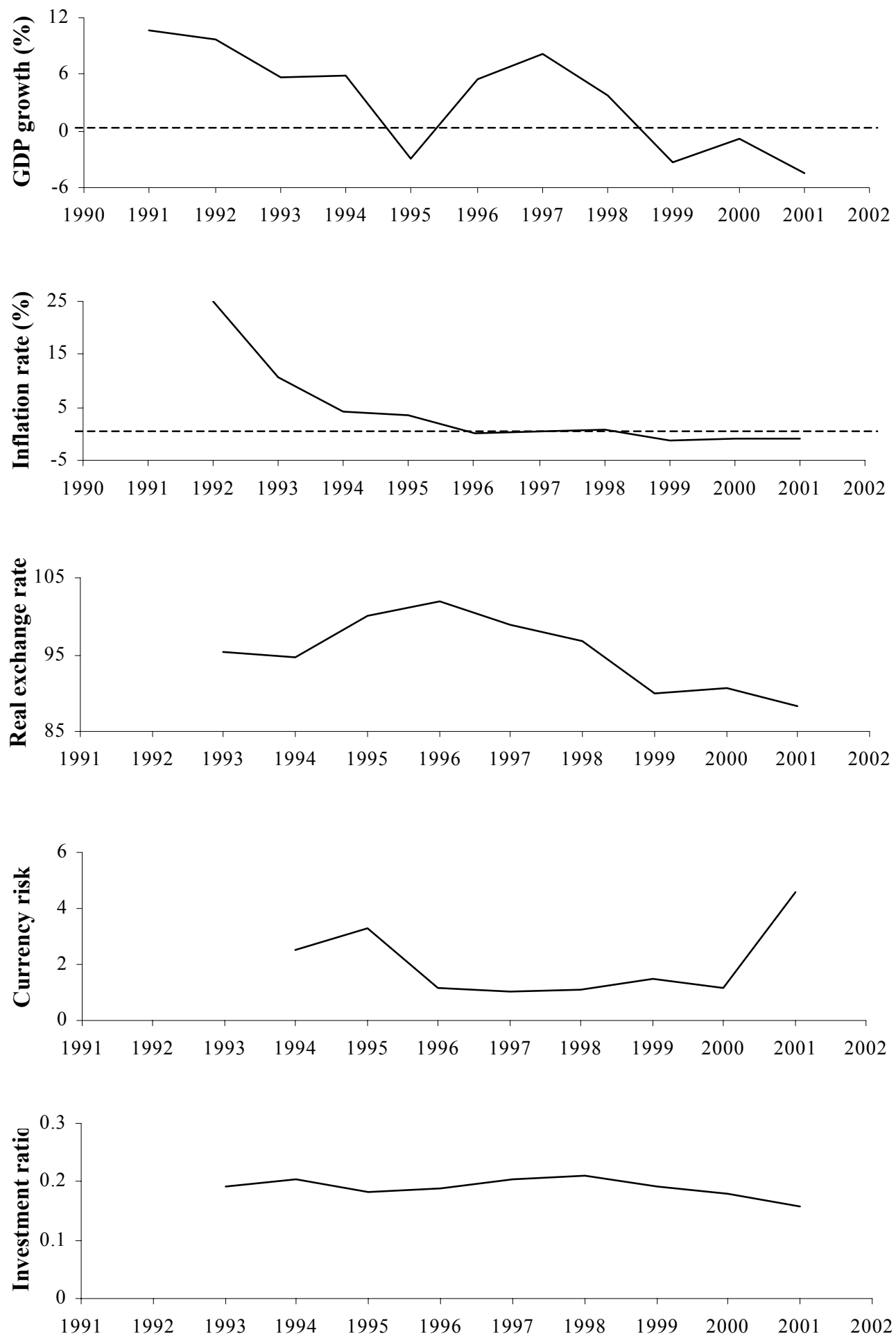


\section{APPENDIX 2: Data Definition and Sources}

\begin{tabular}{|c|c|c|}
\hline Variable & Definition & Source \\
\hline Dollar Ratio & $\begin{array}{l}\text { Ratio of debt denominated in foreign currency } \\
\text { (converted into local currency using the end-of- } \\
\text { period exchange rate) over total debt. }\end{array}$ & $\begin{array}{l}\text { Balance sheet data obtained from } \\
\text { Economatica, Buenos Aires Stock } \\
\text { Exchange, regulatory agencies, and } \\
\text { Inspeccion General de Justicia. }\end{array}$ \\
\hline Leverage Ratio & Ratio of total debt over assets. & See Dollar Ratio. \\
\hline Investment Ratio & $\begin{array}{l}\text { Ratio of purchases of fixed assets net of disposal } \\
\text { of fixed assets over assets. }\end{array}$ & $\begin{array}{l}\text { Cash-flow Statements obtained from } \\
\text { Economatica, Buenos Aires Stock } \\
\text { Exchange, regulatory agencies, and } \\
\text { Inspeccion General de Justicia. }\end{array}$ \\
\hline Sales Ratio & $\begin{array}{l}\text { Ratio of revenue from main operating activities } \\
\text { over assets. }\end{array}$ & $\begin{array}{l}\text { Income Statements obtained from } \\
\text { Economatica, Buenos Aires Stock } \\
\text { Exchange, regulatory agencies, and } \\
\text { Inspeccion General de Justicia. }\end{array}$ \\
\hline Real Sales & $\begin{array}{l}\text { Revenue from main operating activities over } \\
\text { assets in constant pesos. }\end{array}$ & See Sales Ratio. \\
\hline Earnings Ratio & $\begin{array}{l}\text { Ratio of earnings before accrued interest, taxes, } \\
\text { depreciation and amortization over assets. }\end{array}$ & See Investment Ratio. \\
\hline Assets & $\begin{array}{l}\text { Sum of total current assets, long-term } \\
\text { receivables, investment in unconsolidated } \\
\text { subsidiaries, other investments, net property, } \\
\text { plant and equipment, and other assets. }\end{array}$ & See Dollar Ratio. \\
\hline Expo & $\begin{array}{l}\text { Sector export content measured as the export-to- } \\
\text { value added ratio. Firms are assigned to sectors } \\
\text { according to their production mix. }\end{array}$ & Ministry of Finance. \\
\hline Impo & $\begin{array}{l}\text { Sector import content measured as the import- } \\
\text { to-value added ratio. Firms are assigned to } \\
\text { sectors according to their production mix. }\end{array}$ & Ministry of Finance. \\
\hline Deflator & $\begin{array}{l}\text { Sectoral value added at current prices over } \\
\text { sectoral value added at constant prices, } \\
\text { normalized by the GDP deflator. }\end{array}$ & Ministry of Finance. \\
\hline RER & $\begin{array}{l}\text { Real effective exchange rate, measured as the } \\
\text { average bilateral RER vis a vis the country main } \\
\text { trade partners, weighted by the average export } \\
\text { share for } 1995-1999 \text {. }\end{array}$ & ECLAC, based on IMF. \\
\hline CRISK & $\begin{array}{l}\text { Currency risk measured as the differential } \\
\text { between peso and dollar interbank deposit rates, } \\
\text { using daily one-month interest rate premiums. }\end{array}$ & Central Bank of Argentina. \\
\hline Dollar Indexation & $\begin{array}{l}\text { Dummy that equals one for privatized firms in } \\
\text { regulated sectors if rates are indexed by the } \\
\text { United States' Consumer Price Index. }\end{array}$ & Regulatory Agencies. \\
\hline
\end{tabular}




\section{Universidad Torcuato Di Tella, Business School Working Papers}

\section{Working Papers 2003}

NN16 "Business Cycle and Macroeconomic Policy Coordination in MERCOSUR"

Martín Gonzalez Rozada (UTDT) y José Fanelli (CEDES).

No15 "The Fiscal Spending Gap and the Procyclicality of Public Expenditure"

Eduardo Levy Yeyati (UTDT) y Sebastián Galiani (UDESA).

No14 "Financial Dollarization and Debt Deflation under a Currency Board"

Eduardo Levy Yeyati (UTDT), Ernesto Schargrodsky (UTDT) y Sebastián Galiani (UDESA).

№13 " ¿ Por qué crecen menos los regímenes de tipo de cambio fijo? El efecto de los Sudden Stops", Federico Stuzenegger (UTDT).

№12 "Concentration and Foreign Penetration in Latin American Banking Sectors: Impact on Competition and Risk", Eduardo Levy Yeyati (UTDT) y Alejandro Micco (IADB).

№11 "Default 's in the 1990's: What have we learned?",

Federico Sturzenegger (UTDT) y Punan Chuham (WB).

№10 "Un año de medición del Indice de Demanda Laboral: situación actual y perspectivas",

Victoria Lamdany (UTDT) y Luciana Monteverde (UTDT)

N'09 "Liquidity Protection versus Moral Hazard: The Role of the IMF",

Andrew Powell (UTDT) y Leandro Arozamena (UTDT)

№8 "Financial Dedollarization: A Carrot and Stick Approach", Eduardo Levy Yeyati (UTDT)

No07 "The Price of Inconvertible Deposits: The Stock Market Boom during the Argentine crisis",

Eduardo Levy Yeyati (UTDT), Sergio Schmukler (WB) y Neeltje van Horen (WB)

NN06 "Aftermaths of Current Account Crisis: Export Growth or Import Contraction?",

Federico Sturzenegger (UTDT), Pablo Guidotti (UTDT) y Agustín Villar (BIS)

No5 "Regional Integration and the Location of FDI",

Eduardo Levy Yeyati (UTDT), Christian Daude (UM ) y Ernesto Stein (BID)

N04 "A new test for the success of inflation targeting",

Andrew Powell (UTDT), Martin Gonzalez Rozada (UTDT) y Verónica Cohen Sabbán (BCRA)

No03 "Living and Dying with Hard Pegs: The Rise and Fall of Argentina's Currency Board",

Eduardo Levy Yeyati (UTDT), Augusto de la Torre (WB) y Sergio Schmukler (WB)

No02 "The Cyclical Nature of FDI flows",

Eduardo Levy Yeyati (UTDT), Ugo Panizza (BID) y Ernesto Stein (BID) 
№1 "Endogenous Deposit Dollarization",

Eduardo Levy Yeyati (UTDT) y Christian Broda (FRBNY)

\section{Working Papers 2002}

№15 "The FTAA and the Location of FDI",

Eduardo Levy Yeyati (UTDT), Christian Daude (UM ) y Ernesto Stein ( BID)

No14 "Macroeconomic Coordination and Monetary Unions in a N-country World: Do all Roads

Lead to Rome?"

Federico Sturzenegger (UTDT) y Andrew Powell (UTDT)

№13 "Reforming Capital Requirements in Emerging Countries"

Andrew Powell (UTDT), Verónica Balzarotti (BCRA) y Christian Castro (UPF)

№12 "Toolkit for the Analysis of Debt Problems", Federico Sturzenegger (UTDT)

№11 "On the Endogeneity of Exchange Rate Regimes",

Eduardo Levy Yeyati (UTDT), Federico Sturzenegger (UTDT) e lliana Reggio (UCLA)

№10 "Defaults in the 90's: Factbook and Preliminary Lessons", Federico Sturzenegger (UTDT)

No09 "Countries with international payments ' difficulties: what can the IMF do?"

Andrew Powell (UTDT)

NN08 "The Argentina Crisis: Bad Luck, Bad Management, Bad Politics, Bad Advice",

Andrew Powell (UTDT)

N07 "Capital Inflows and Capital Outflows: Measurement, Determinants, Consequences",

Andrew Powell (UTDT), Dilip Ratha (WB) y Sanket Mohapatra (CU)

No06 "Banking on Foreigners: The Behaviour of International Bank Lending to Latin America, 1985-2000",

Andrew Powell (UTDT), María Soledad Martinez Peria (WB) y Ivanna Vladkova ( IMF)

No05 "Classifying Exchange Rate Regimes: Deeds vs. Words"

Eduardo Levy Yeyati (UTDT) y Federico Sturzenegger (UTDT)

NN04 "The Effect of Product Market Competition on Capital Structure: Empirical Evidence from the

Newspaper Industry", Ernesto Schargrodsky (UTDT)

N03 "Financial globalization: Unequal blessings",

Augusto de la Torre (World Bank), Eduardo Levy Yeyati (Universidad Torcuato Di Tella) y Sergio

L. Schmukler (World Bank)

N02 "Inference and estimation in small sample dynamic panel data models",

Sebastian Galiani (UdeSA) y Martin Gonzalez-Rozada (UTDT)

№1 "Why have poverty and income inequality increased so much? Argentina 1991-2002",

Martín González-Rozada, (UTDT) y Alicia Menendez, (Princeton University). 